Werner F.M. De Bondt University of Wisconsin-Madison

\title{
Earnings Forecasts and Share Price Reversals
}

The Research Foundation of The Institute of Chartered Financial Analysts 


\section{Research Foundation Publications}

Canadian Stocks, Bonds, Bills, and Inflation: 1950-1987

by James E. Hatch and Robert E. White

Closed-Form Duration Measures and Strategy Applications

by Nelson J. Lacey and Sanjay K. Nawalkha

Corporate Bond Rating Drift: An Examination of Credit Quality Rating

Changes Over Time

by Edward I. Altman and Duen Li Kao

Default Risk, Mortality Rates, and the Performance of Corporate Bonds by Edward I. Altman

Durations of Nondefault-Free Securities

by Gerald O. Bierwag and George G. Kaufman

The Effect of Illiquidity on Bond Price Data: Some Symptoms and Remedies by Oded Sarig and Arthur Warga

The Founders of Modern Finance: Their Prize-winning Concepts and 1990 Nobel Lectures

Initial Public Offerings: The Role of Venture Capitalists

by Joseph T. Lim and Anthony Saunders

A New Perspective on Asset Allocation

by Martin L. Leibowitz

The Poison Pill Anti-takeover Defense: The Price of Strategic Deterrence

by Robert F. Bruner

Program Trading and Systematic Risk

by A.J. Senchack, Jr., and John D. Martin

The Role of Risk Tolerance in the Asset Allocation Process: A New Perspective by W.V. Harlow III, CFA, and Keith C. Brown, CFA

Selecting Superior Securities

by Marc R. Reinganum

Stock Market Structure, Volatility, and Volume

by Hans R. Stoll and Robert E. Whaley

Stocks, Bonds, Bills, and Inflation: Historical Returns (1926-1987)

by Roger G. Ibbotson and Rex A. Sinquefield

(Published with Business One Irwin) 


\section{Earnings Forecasts and Share Price Reversals}


(1) 1992 The Research Foundation of the Institute of Chartered Financial Analysts.

All rights reserved. No part of this publication may be reproduced, stored in a retrieval system, or transmitted, in any form or by any means, electronic, mechanical, photocopying, recording, or otherwise, without the prior written permission of the copyright holder.

This publication is designed to provide accurate and authoritative information in regard to the subject matter covered. It is sold with the understanding that the publisher is not engaged in rendering legal, accounting, or other professional service. If legal advice or other expert assistance is required, the services of a competent professional should be sought.

From a Declaration of Principles jointly adopted by a Committee of the American Bar Association and a Committee of Publishers.

ISBN 10-digit: 0-943205-13-1 ISBN 13-digit: 978-0-943205-13-7

Printed in the United States of America

April 1992 


\section{Mission}

The mission of the Research Foundation is to identify, fund, and publish research material that:

- expands the body of relevant and useful knowledge available to practitioners;

- assists practitioners in understanding and applying this knowledge; and

- enhances the investment management community's effectiveness in serving clients.

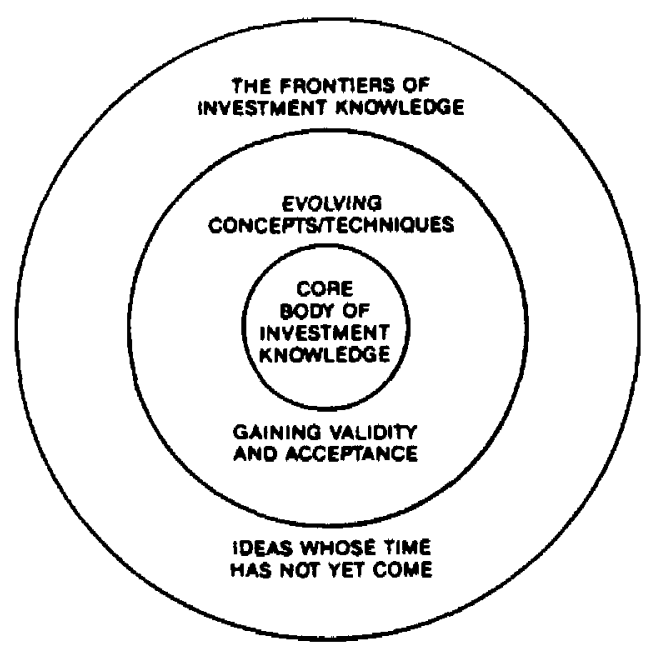

The Research Foundation of

The Institute of Chartered Financial Analysts

P. O. Box 3668

Charlottesville, Virginia 22903

Telephone: 804/977-6600

Fax: 804/977-1103 


\section{Table of Contents}

Acknowledgements.$\ldots \ldots \ldots \ldots \ldots \ldots \ldots \ldots$ viii

Foreword $\ldots \ldots \ldots \ldots \ldots \ldots \ldots \ldots \ldots \ldots \ldots$ ix

Chapter 1. Introduction $\ldots \ldots \ldots \ldots \ldots \ldots \ldots \ldots, 1$

Chapter 2. Data and Empirical Methods .......... 5

Chapter 3. Are Market Forecasts of Earnings Growth Too Extreme?.................. 15

Chapter 4. Risk and Return .............. 27

Chapter 5. Conclusion................... 33

References ......................... 35 


\section{Acknowledgements}

I thank the Research Foundation of the Institute of Chartered Financial Analysts for generous financial support. I am especially grateful to Charles D'Ambrosio (the research director) for his constructive comments and encouragement. Early versions of this study were presented at the Behavioral Finance Workshop of the NBER Summer Institute, the Contrary Opinion Forum, the Decision Theory Seminar organized by the Investment Analysts Society of Chicago, Michigan State University, and the University of Wisconsin-Madison. I thank Andrew Alford, Mary Bange, Victor Bernard, T. Daniel Coggin, David Cutler, Josef Lakonishok, Jay Ritter, Steve Raymar, Richard Thaler, and John Wild for comments. I also thank Dale Berman (IBES, Inc.) and Bart Wear (First Wisconsin Asset Management) for supplying the earnings forecast data used in this study. Finally, I thank Jim Fraser, Luke Knecht, Steven Nichols, and William Warnke for inviting me to present parts of the study to investment professionals.

Werner F.M. De Bondt 


\section{Foreword}

Stock momentum and excessive price movements are part of Wall Street lore. Technicians call these trends; fundamentalists dub them irregularities. De Bondt's study analyzes such price movements.

Because excessive moves are observable and yet contrary to accepted doctrine, the author urges better theories of asset valuation. In that connection, he focuses on analysts' earnings-per-share forecasts and the role the forecasts play in these excessive moves. Specifically, the study examines whether prices are realistically related to analysts' optimistic or pessimistic earnings growth forecasts. The data cover the period 1973-86.

One major conclusion of the study is that contrarian strategies seem to work. In itself, that might not seem very revealing inasmuch as the past 20 years or so have witnessed a plethora of readings regarding contrarian investing. Indeed, as with so many other ideas, the idea is found in Graham and Dodd, and before that in Alfred Marshall's representative firm, in which prices tend to converge to an average. But remember that the notion is not rigorously and scientifically documented. It is part of Wall Street lore but not necessarily part of its reality. De Bondt documents, forcefully, the success of a contrarian strategy based on excessive price moves. Moreover, he demonstrates what growth valuation models suggest, namely that abnormal performance tends to grow with the horizon over which earnings per share are forecasted.

There is a story within the story of De Bondt's work that deserves to be told here. I have noted elsewhere* that the 1990 Nobel Prize in Economic Sciences, awarded to Markowtiz, Miller, and Sharpe, ushers in a new era of financial analysis and investment management. When "our" Laureates are juxtaposed with such other Nobel prize winners as Albert Einstein, Marie S. Curie, Martin Luther King Jr., Thomas Mann, John Steinbeck, and Linus Pauling, the basis is established by which to define the world's expectations for our business. This high level of expectations warrants a high level of delivery.

To aid and abet effective delivery, modelling has become the byword of financial analysis. If I were to select a model of modelling, De Bondt's would be

*"Foreword." The Founders of Modern Finance: Their Prize-Winning Concepts and 1990 Nobel Lectures (Charlottesville, Virginia: The Research Foundation of the Institute of Chartered Financial Analysts, 1991). 
it. To see what I mean, pay particular attention as you read this monograph to the headings as well as the information contained in each section. Take a look at the methodical, straightforward manner in which the basic idea is presented. Note how each step is documented by reference to prior studies, both those found wanting and those which now form the core of our knowledge set. De Bondt presents us with the following modality of full disclosure in research:

Here is the problem

Here is what I propose to do about it

Here are the data and its limitations

Here are the testable hypotheses

Here are the tests

Here are the results

Here are the conclusions derived from the analysis

Notice also how the results are presented in a section apart from conclusions. Analysts know that the numbers speak for themselves; one cannot "talk" to the numbers when the actual results differ from those that are desired. Verily, it is difficult to accept results for what they are in light of preconceptions. That is why a results section is part and parcel of any study: When the numbers speak, analysts are obligated to listen, for only then may they form conclusions and derive inferences. One is not entitled to speculate or editorialize until the analysis is completed and the results have been separately presented.

The Research Foundation takes pleasure in bringing De Bondt's research before you, both because of what he does and because of how he does it.

Charles A. D'Ambrosio, CFA

Research Director

The Research Foundation of

The Institute of Chartered Financial Analysts 


\section{Introduction}

In recent years, our understanding of stock valuation has been greatly influenced by three developments: (1) the failure of standard frameworks-such as the capital asset pricing model (CAPM) or consumption-based asset pricing models - to account for stock price movements; (2) the emergence of a large literature on stock market anomalies; and (3) the reopening of the "efficient markets debate" with the work on excess volatility, on the predictability of twoto five-year stock returns, and on the reasons for the 1987 stock market crash. All three empirical developments have created a new urgency for the finance profession to devise better theories of asset valuation. Of course, market efficiency imposes few restrictions on the behavior of expected returns. Logically, time-varying risk premiums may still account for the evidence. Also, we may be able to salvage rational agent models by introducing information costs or other frictions (see Merton 1987).

An altogether different and novel approach is to focus on investor psychology. Fads and fashions are likely to drive a wedge between prices and fundamental values (De Long et al. 1990, Shiller 1990, Shleifer and Summers 1990). This study elaborates on previous research by De Bondt and Thaler $(1985,1987,1990)$ on investor overreaction. The psychological foundations of the theory consist of work by Kahneman and Tversky $(1972,1973)$ on heuristics and biases, intuitive prediction, and Bayesian updating (in De Bondt and Thaler 1985), in which large price run-ups or price declines serve as proxies for excessive market optimism or pessimism. Consistent with market overreaction, prior winner and loser stocks experience predictable price reversals.

One interpretation of share price reversals is the earnings-fad, "castle-inthe-air" hypothesis explored in De Bondt and Thaler (1987). Perhaps the representative agent systematically misperceives the stochastic properties of 
the earnings process. ${ }^{1}$ Even though company earnings have temporary meanreverting components (Brooks and Buckmaster 1976), traders either think all earnings changes to be permanent or, worse, detect "trends." As the original expectations get disappointed, stock prices adjust. In other words, mean reversion in stock prices reflects mean reversion in earnings, which many investors fail to recognize.

The earnings profiles of winner and loser companies broadly match the price movements of their stocks. This is consistent with overreaction to past earnings. As mentioned in De Bondt and Thaler (1990), however, only a small part of the variation in security analyst earnings forecasts is directly explained by past earnings or stock price trends. Nevertheless, analysts' forecasts of oneand two-year changes in earnings per share (EPS) are systematically too extreme. Thus, the data confirm a "generalized" overreaction bias in expectations, but pinpointing its source is difficult.

The evidence on analysts' EPS forecasts has important implications for market rationality. Few will argue with the fact that the typical investor in the United States does not have the time nor the skill to produce earnings forecasts of superior quality. Thus, it would not be surprising if the average investor attaches great weight to irrelevant information or trades on illusory trends. In contrast, security analysts are experts in their field and, compared with everyone else, they represent "smart money." After all, they sell (rather than buy) earnings forecasts. If even experts overreact, market overreaction becomes plausible. To whatever extent analysts' opinions get amplified through trading, the quality of their forecasts represents a natural upper bound to the quality of market forecasts.

This study in behavioral finance tests whether market prices contain unrealistically optimistic or pessimistic forecasts of future earnings growth. The data base consists of analyst survey data combined with price and accounting data for the period between 1973 and 1986. Companies were sorted into portfolios on the basis of one-, two-, and five-year growth in EPS, as predicted by analysts. If market expectations mirror analyst expectations, a contrarian strategy that bets against the analysts should be successful in generating excess returns. The data suggest that this is the case.

Interestingly, the abnormal performance appears to grow with the horizon for which EPS is predicted. As dividend discount models show, price movements now may result from new information about earnings in the distant future. Thus, if overreaction bias exists, it is not clear whether the tests should

\footnotetext{
${ }^{1}$ Throughout the text, I use the terms "earnings" and "earnings per share" interchangeably.
} 
be applied to expectations of this year's earnings, next year's, a decade from now, or to all these cases. Market folklore has it that share prices at times discount "not only the future but also the hereafter" (Malkiel 1963, p. 1025). This Wall Street aphorism suggests that long-term earnings forecasts are most relevant to share price reversals. ${ }^{2}$ The evidence this study presents is consistent with that point of view.

${ }^{2}$ Also, De Bondt and Thaler (1990) show that analysts, as they prepare their forecasts, essentially have no predictive power for earnings changes from the current year to the next (in fact, they only have moderate predictive power for earnings changes from last year to the current year). Thus, medium- and long-term forecasts almost amount to pure error or "pie in the sky." 



\section{Data and Empirical Methods}

This chapter describes the empirical methods that were used to select the stocks in the sample. It also lists various sample descriptors and presents a novel way to test for market overreaction. In contrast to previous studies, the methods are specifically designed to examine market overreaction to information about future earnings.

\section{Sample Selection}

The data for this study come from three sources: (1) analysts' earnings forecasts, from the tapes produced by IBES, Inc.; (2) accounting data, from Standard \& Poor's annual industrial (main and delisted) COMPUSTAT files; and (3) stock returns, from the Center for Research in Security Prices (CRSP) at the University of Chicago. Because all three data sources contain full historical records, no survivorship bias of any kind affects the results.

The sample was selected as follows: ${ }^{3}$

1. For the one- and two-year earnings forecasts available on IBES every April between 1976 and 1984, let $t$ be the year that the April forecasts are made. Then, FEPS $(t)$ denotes the April forecast of earnings-per-share for the current year, and $F E P S(t+1)$ denotes the forecast for year $t+1$. All forecasts are consensus forecasts in that they are either the mean or the median of the analysts' predictions. To enter the sample, a company must have a December fiscal year, and computation of the eight-month forecast revision for its $E P S(t)$ must be possible. In other words, IBES must report a December forecast of $E P S(t)$.

\footnotetext{
${ }^{3}$ This sample selection procedure is similar but not identical to that used in De Bondt and Thaler (1990).
} 
2. For 1982 to 1984 , the five-year earnings growth that analysts projected was also examined. (These data are not available for earlier years.)

3. The stocks that qualify for steps one and two were matched with earnings data from COMPUSTAT. Earnings data from years $t-10$ to $t+1$ were needed. Care was taken to adjust for stock splits, stock dividends, and similar events so that earnings figures and forecasts are expressed on a comparable basis.

4. Companies must have been listed on the New York Stock Exchange (NYSE) or the American Stock Exchange (AMEX), and monthly return data (with no missing values) had to be available for 36 months prior to the April forecast and 21 months after April. This provides a continuous series of 58 monthly returns for each security.

Almost the entire empirical analysis was built upon forecasts of one-, two-, and five-year EPS growth ( $F C 1, F C 2$, and $F C 5) . F C 1$ is computed as $F E P S(t)$ - EPS $(t-1)$ and $F C 2$ as $F E P S(t+1)-E P S(t-1)$, where EPS represents actually realized earnings per share. Both $F C 1$ and $F C 2$ are normalized by the standard deviation of $E P S$ between years $t-10$ and $t-2$. FC5 is the expected annual percentage growth in earnings per share for the next five years.

The tests are based upon vitile (20) portfolios consisting of equal numbers of companies classified according to earnings growth. ${ }^{4}$ To save space, many of the tables below show results for quintile and decile portfolios. Table 1 lists the number of firms in each yearly sample.

\section{Tests of the Overreaction Hypothesis}

If the market expectation of earnings mirrors analyst expectations that are too extreme, then companies with low expected growth will on average be undervalued and companies with high expected growth will be overvalued. Previous research (De Bondt and Thaler 1985) suggests that the time needed for a significant misvaluation partly to correct itself is between one and three years. ${ }^{5}$ For this reason, the return performance of the earnings growth portfolios were followed for 21 months after the forecast month (April), starting in May of the forecast year $(t)$. This test period includes two Januarys (in years

\footnotetext{
${ }^{4}$ To make sure that each earnings-growth portfolio has exactly the same number of companies, I arbitrarily removed a small number of firms placed between portfolios 10 and 11 .

${ }^{5}$ To the best of my knowledge, Benjamin Graham was the first author to suggest that the time span for significant price corrections is one and one-half to two and one-half years. See The Intelligent Investor (New York: Harper \& Brothers, 1949).
} 


\section{TABLE 1. Number of Companies in Samples, 1976-1984}

\begin{tabular}{lccc}
\hline Forecast Year $(t)$ & $\begin{array}{c}\text { One-Year } \\
\text { Forecasts }\end{array}$ & $\begin{array}{c}\text { Two-Year } \\
\text { Forecasts }\end{array}$ & $\begin{array}{r}\text { Five-Year } \\
\text { Forecasts }\end{array}$ \\
\hline & & & - \\
1976 & 340 & 100 & - \\
1977 & 460 & 140 & - \\
1979 & 560 & 340 & - \\
1980 & 720 & 360 & - \\
1981 & 720 & 420 & 640 \\
1982 & 740 & 540 & 680 \\
1983 & 740 & 540 & 680 \\
1984 & 720 & 580 & \\
& 720 & 3,540 & 2,000 \\
\hline
\end{tabular}

$t+1$ and $t+2$ ), months of considerable interest in connection with market anomalies.

Monthly excess returns were computed for each company. The excess returns are defined relative to (1) the equally weighted monthly return for all firms in each yearly sample, (2) the returns earned by companies in the same industry, and (3) the returns earned by companies of comparable market value at the end of year $t-1$. The excess returns were averaged for each portfolio and cumulated. Finally, the cumulative excess returns for each sample year were averaged.

Let portfolio 1 be the lowest and portfolio 20 the highest expected-earningsgrowth portfolio, and let $C A R 1_{m}$ and $C A R 20_{m}$ represent their respective cumulative average excess returns for month $m$ of the test period ( $m=$ $1, \ldots, 21)$. Then, if the market expectation behaves like analyst expectations, it is predicted, first, that $C A R 1_{m}>C A R 2_{m}>\ldots>C A R 20_{m}$, and second, that this pattern in returns becomes more pronounced as the test period advances-that is, as $m$ rises. After all, it may take time for market forecasts to be proven wrong by reality.

A third hypothesis motivated by analysts' behavior is that the return reversals should be larger for longer term forecasts. Less is known about the distant than about the near future. Notwithstanding this fact, analysts are often willing to go out on a limb and produce an extreme forecast. Because their crystal ball is clouded, the overreaction bias for longer term predictions is stronger. Consider now an imaginary arbitrage portfolio that finances stock 
purchases of firms for which analysts show pessimism by selling short companies about which they are optimistic. Let $A R B^{y}{ }_{m}$ be the $m$-month cumulative excess return for an arbitrage portfolio based on $y$-year forecasts. As $m$ rises, then $A R B_{m}^{5}>A R B_{m}^{2}>A R B^{1}{ }_{m}$.

On the other hand, if markets are rational-and analyst-expected earnings growth does not proxy for fundamental determinants of returns-no relationship between projected earnings growth and returns is predicted at any horizon $m$. Thus, one cannot reject that $C A R 1_{m}=C A R 2_{m}=\ldots=C A R 20_{m}$. The prediction applies equally to one-, two-, and five-year forecasts so that $A R B^{5}{ }_{m}$ $=A R B^{2}{ }_{m}=A R B^{1}{ }_{m}$.

Much previous research on the price effects of earnings announcements argues that the stock market tends to underreact to earnings news. (For a review of this literature, see Bernard 1991.) If, contrary to the view of De Bondt and Thaler (1990), analysts' earnings expectations are sluggish, and if the market underreacts to earnings information in the same way, then $C A R 1_{m}<$ $C A R 2_{m}<\ldots<C A R 20_{m}$. In this case, the market's underreaction should also become more clear as time goes on. Not obvious is whether this hypothesis predicts more underreaction to news about distant earnings than about nearby earnings.

The simplest possible tests were used to establish a link between returns and expected earnings growth. For each $m=1, \ldots, 21$, Spearman rank correlations were calculated between the cumulative excess returns and the ranks of the earnings-growth portfolios $(R=1, \ldots, 20)$. Also, for various subperiods, the cumulative excess returns were regressed on $R$.

In addition, the methods of Rendleman et al. (1982) were used to see whether the extreme quintile portfolios (Q1 and Q5) and an arbitrage portfolio (Q1 - Q5) earned cumulative excess returns that are statistically different from zero. To test for the significance of the cumulative excess returns, estimates of their variances are necessary. Let $A R_{i}$ be the average excess return for any month of the test period, and let $A R^{*}=1 / m\left(\Sigma A R_{i}\right)$, where $i=1, \ldots, m$. Then, allowing for first-order serial correlation in the average excess returns, for any portfolio $\operatorname{VAR}\left(C A R_{m}\right)=m^{*} \operatorname{VAR}\left(A R_{i}\right)+2(m-1)^{*} \operatorname{COV}\left(A R_{i}, A R_{i-1}\right)$. The variance of $A R_{i}$ is equal to $1 /(m-1)\left[\Sigma\left(A R_{i}-A R^{*}\right)^{2}\right]$, and the first-order covariance is $1 /(m-2)\left[\Sigma\left(A R_{i}-A R^{*}\right)\left(A R_{i+1} A R^{*}\right)\right]$. The $t$-statistics are equal to $C A R_{m} / \sqrt{\operatorname{VAR}\left(C A R_{m}\right)}$.

Companies with poor earnings prospects could possibly command higher expected returns because they are irrationally perceived to be very risky and undesirable. Also possible is that these companies are objectively more risky in the context of large diversified portfolios and that they have larger CAPM betas. The second issue is critical from the perspective of rational agent 
models. Chapter 4 uses the methods of Ball and Kothari (1989) to control for objective beta risk. For now, the use of market-adjusted (or industry- and size-adjusted) excess returns implicitly assumes that all companies in the sample (or within an industry or size class) are of equal risk.

Much of the difficulty of forecasting earnings for individual companies has to do with unanticipated macroeconomic and industrywide shocks (Elton et al. 1984, O'Brien 1991). Market- and industry-adjusted returns were used to try to control for this problem. Of course, if firms are differentially affected, the controls are not perfect. Consider unexpected bad news and the increased likelihood of recession. If investors' earnings forecasts and stock prices for companies with an already bleak outlook rationally suffer less from this news than do the forecasts and prices for companies with a bright future, then the excess return data falsely suggest market overreaction. On the other hand, to the degree that market- and industrywide fads influence earnings projections and stock returns, the test period excess returns understate overreaction.

\section{Characteristics of the Sample Period and Companies}

Figure 1 shows nominal and real income (in 1980 dollars) for the average company in the samples. Because so many firms enter and leave the samples,

\section{FIGURE 1. Mean Corporate Income, 1971-85}

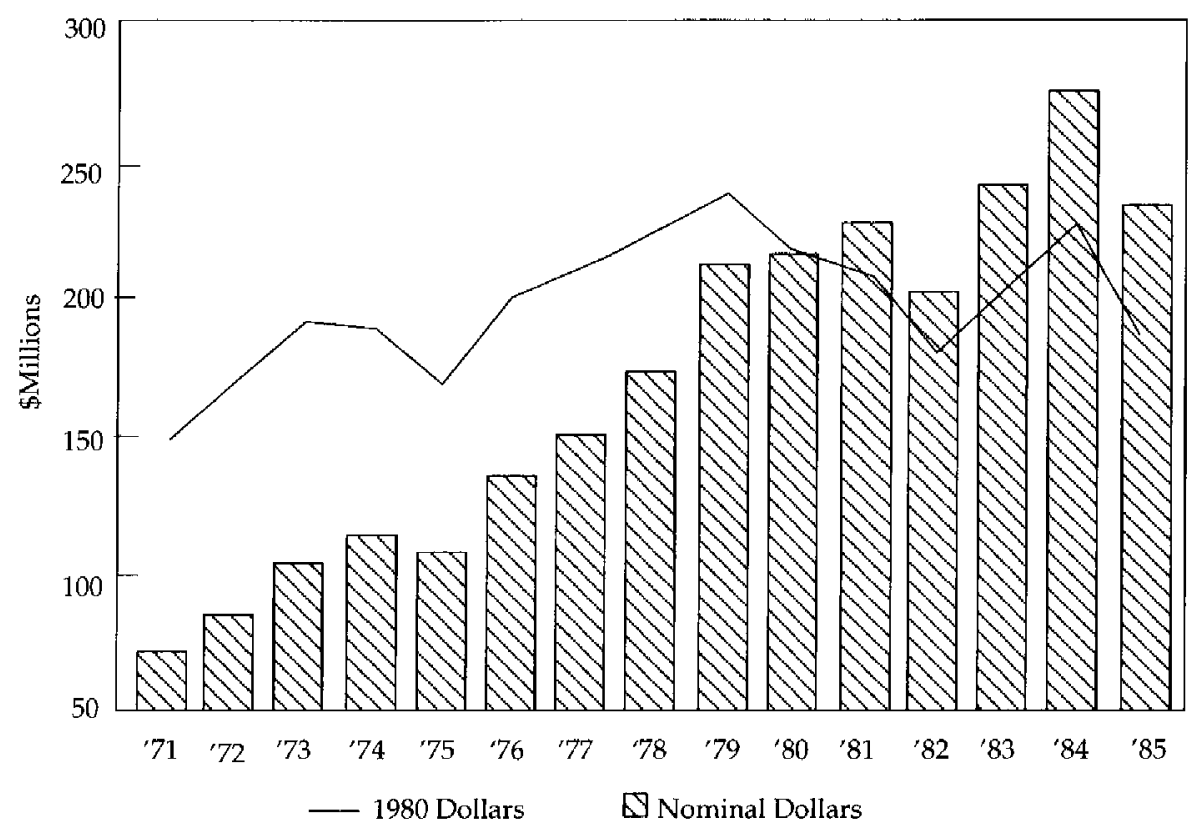


FIGURE 2. Stock Market Indexes, April 1973-January 1986

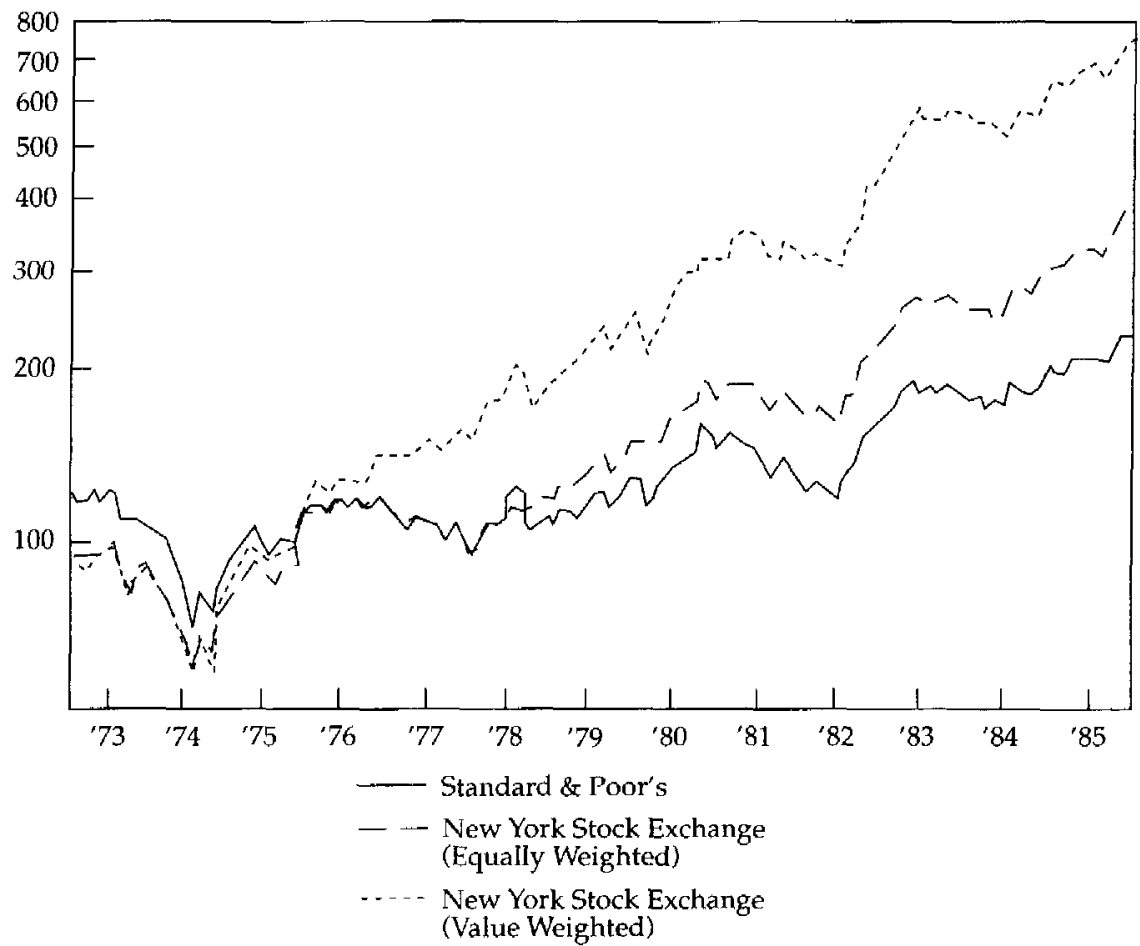

the figure is drawn for 290 "survivors" that have continuous earnings data between 1971 and 1985 . The nine years for which earnings forecasts are available, 1976 to 1984, are of particular interest. During this period, real profits fell in 1980, 1981, and 1982. They rose in all other years. In 1984, however, earnings were still slightly below 1979 earnings.

Figure 2 shows aggregate stock returns for three indexes between April 1973 and January 1986: (1) an equally weighted index of all companies listed on the NYSE, (2) a value-weighted index of all NYSE companies, and (3) the Standard \& Poor's Index of 425 industrials. The NYSE indexes are set equal to 100 in April 1973. From 1975 onward, low-capitalization stocks dramatically outperformed high-capitalization stocks, although the movements in the stock indexes show the same general pattern as in Figure 1. For example, share prices fell during the $1980-82$ period.

Figures 1 and 2 mask considerable cross-sectional variation in the changing 


\section{TABLE 2. Industry Composition of Samples (percent of sample)}

\begin{tabular}{lccc}
\hline Industry & $\begin{array}{c}\text { One-Year } \\
\text { Forecasts }\end{array}$ & $\begin{array}{c}\text { Two-Year } \\
\text { Forecasts }\end{array}$ & $\begin{array}{c}\text { Five-Year } \\
\text { Forecasts }\end{array}$ \\
\hline Apparel & & & \\
Automobile & $2.3 \%$ & $1.2 \%$ & $1.8 \%$ \\
Business Equipment & 1.9 & 1.8 & 2.0 \\
Chemical & 12.6 & 12.9 & 13.1 \\
Construction & 4.4 & 4.9 & 4.2 \\
Drug & 5.2 & 5.2 & 5.2 \\
Durables & 4.2 & 5.1 & 3.5 \\
Financial & 7.1 & 6.2 & 7.0 \\
Food & 9.4 & 8.6 & 10.9 \\
Metal & 3.0 & 2.3 & 2.5 \\
Metal Products & 2.9 & 3.0 & 2.9 \\
Mining & 2.6 & 2.5 & 3.0 \\
Miscellaneous & 2.2 & 1.6 & 2.0 \\
Petroleum & 11.9 & 12.7 & 10.9 \\
Retail & 6.6 & 7.8 & 6.1 \\
Transportation & 2.6 & 1.9 & 2.5 \\
Utilities & 5.9 & 6.2 & 6.0 \\
Other & 15.0 & 15.7 & 16.4 \\
& 0.4 & 0.4 & 0.4 \\
Total & & & $100.0 \%$ \\
\hline N & $100.0 \%$ & $100.0 \%$ &
\end{tabular}

Note: Industries are defined as in Fama and French (1988).

fortunes of different industry sectors. For example, total nominal profits for six major companies in the automobile industry were as follows: $\$ 5.4$ billion (1978), $-\$ 2.0$ billion (1980), $\$ 582$ million (1982), and $\$ 7.9$ billion (1984). In contrast, the total earnings of utilities increased every year between 1971 and 1984. The profits of the petroleum industry first rose each year through 1981 and thereafter fell each year through 1985. Table 2 shows the composition by industry of the pooled yearly samples. The entries are the number of firms in each industry as a percentage of all companies. Industries are defined as in Fama and French (1988). The largest groups are utilities, miscellaneous, and business equipment.

Some industries are disproportionately represented in the extreme earnings-growth portfolios. Table 3 lists those industries for which significantly 
TABLE 3. Optimism/Pessimism About Earnings Growth by Year and by Industry

\begin{tabular}{|c|c|c|c|c|c|c|c|c|}
\hline \multirow[b]{3}{*}{ Year } & \multicolumn{8}{|c|}{ Projected Earnings Growth } \\
\hline & \multicolumn{4}{|c|}{ Low (Q1) } & \multicolumn{4}{|c|}{ High (Q5) } \\
\hline & Industry & $\begin{array}{c}\% \text { of } \\
\text { Sample }\end{array}$ & $\begin{array}{c}\% \text { of } \\
\text { Quintile }\end{array}$ & $\begin{array}{c}\% \text { of } \\
\text { Industry }\end{array}$ & Industry & $\begin{array}{c}\% \text { of } \\
\text { Sample }\end{array}$ & $\begin{array}{c}\% \text { of } \\
\text { Quintile }\end{array}$ & $\begin{array}{c}\% \text { of } \\
\text { Industry }\end{array}$ \\
\hline \multicolumn{9}{|c|}{ One-Year Forecasts } \\
\hline 1976 & UTIL & 17.4 & 27.9 & 32.2 & AUTO & 2.1 & 5.9 & 57.1 \\
\hline 1977 & & & & & DURA & 6.3 & 14.1 & 44.8 \\
\hline 1978 & TRAN & 7.0 & 12.5 & 35.9 & & & & \\
\hline \multirow[t]{3}{*}{1979} & AUTO & 1.9 & 4.2 & 42.9 & MINE & 2.9 & 5.6 & 38.1 \\
\hline & CONS & 5.3 & 10.4 & 39.5 & & & & \\
\hline & TRAN & 5.7 & 9.7 & 34.1 & & & & \\
\hline \multirow[t]{3}{*}{1980} & AUTO & 1.8 & 5.6 & 61.5 & MINE & 2.2 & 5.6 & 50.0 \\
\hline & CONS & 5.3 & 11.1 & 42.1 & OIL & 6.7 & 16.0 & 47.9 \\
\hline & METL & 3.3 & 7.6 & 45.8 & UTIL & 14.4 & 20.8 & 28.8 \\
\hline \multirow[t]{3}{*}{1981} & METL & 3.0 & 6.8 & 45.5 & AUTO & 1.8 & 4.7 & 53.8 \\
\hline & MINE & 2.2 & 4.7 & 43.8 & OIL & 6.6 & 11.5 & 34.7 \\
\hline & UTIL & 14.5 & 20.3 & 28.0 & & & & \\
\hline 1982 & METL & 2.8 & 8.8 & 61.9 & & & & \\
\hline 1983 & OIL & 5.8 & 16.0 & 54.8 & METL. & 2.5 & 4.9 & 38.9 \\
\hline \multirow[t]{2}{*}{1984} & OIL & 6.3 & 10.4 & 33.3 & BSEQ & 12.4 & 18.8 & 30.3 \\
\hline & UTIL & 15.6 & 46.5 & 59.8 & METL & 2.2 & 7.7 & 68.8 \\
\hline \multicolumn{9}{|c|}{ Two-Year Forecasts } \\
\hline 1976 & OIL & 14.0 & 35.0 & 50.0 & CHEM & 7.0 & 20.0 & 57.1 \\
\hline \multirow[t]{4}{*}{1978} & APPA & 0.6 & 2.9 & 100.0 & & & & \\
\hline & AUTO & 1.5 & 4.4 & 60.0 & & & & \\
\hline & CHEM & 4.7 & 11.8 & 50.0 & & & & \\
\hline & TRAN & 5.0 & 10.3 & 41.2 & & & & \\
\hline \multirow[t]{2}{*}{1979} & APPA & 0.8 & 2.8 & 66.7 & & & & \\
\hline & METL & 4.7 & 12.5 & 52.9 & & & & \\
\hline \multirow[t]{2}{*}{1980} & METL & 3.3 & 8.3 & 50.0 & APPA & 0.5 & 2.4 & 100.0 \\
\hline & MISC & 12.1 & 20.2 & 33.3 & OIL & 7.9 & 19.0 & 48.5 \\
\hline \multirow[t]{3}{*}{1981} & METL & 2.5 & 6.7 & 53.8 & AUTO & 1.5 & 3.8 & 50.0 \\
\hline & MINE & 1.0 & 2.9 & 60.0 & OIL & 7.1 & 13.5 & 37.8 \\
\hline & UTIL & 16.9 & 31.7 & 37.5 & & & & \\
\hline \multirow[t]{3}{*}{1982} & METL & 3.0 & 11.1 & 75.0 & FINA & 10.7 & 17.6 & 32.8 \\
\hline & MINE & 1.7 & 4.6 & 55.6 & & & & \\
\hline & UTIL & 16.3 & 24.1 & 29.5 & & & & \\
\hline
\end{tabular}


TABLE 3-Continued

\begin{tabular}{|c|c|c|c|c|c|c|c|c|}
\hline \multirow[b]{3}{*}{ Year } & \multicolumn{8}{|c|}{ Projected Earnings Growth } \\
\hline & \multicolumn{4}{|c|}{ Low (Q1) } & \multicolumn{4}{|c|}{ High (Q5) } \\
\hline & Industry & $\begin{array}{c}\% \text { of } \\
\text { Sample }\end{array}$ & $\begin{array}{c}\% \text { of } \\
\text { Quintile }\end{array}$ & $\begin{array}{c}\% \text { of } \\
\text { Industry }\end{array}$ & Industry & $\begin{array}{c}\% \text { of } \\
\text { Sample }\end{array}$ & $\begin{array}{c}\% \text { of } \\
\text { Quintile }\end{array}$ & $\begin{array}{c}\% \text { of } \\
\text { Industry }\end{array}$ \\
\hline \multicolumn{9}{|c|}{ Two-Year Forecasts (cont.) } \\
\hline 1983 & $\begin{array}{l}\text { OIL } \\
\text { UTIL }\end{array}$ & $\begin{array}{r}6.3 \\
16.7\end{array}$ & $\begin{array}{l}20.4 \\
31.5\end{array}$ & $\begin{array}{l}64.7 \\
37.8\end{array}$ & CONS & 4.8 & 11.1 & 46.2 \\
\hline 1984 & $\begin{array}{l}\text { OIL } \\
\text { UTIL }\end{array}$ & $\begin{array}{r}7.4 \\
16.9\end{array}$ & $\begin{array}{l}14.7 \\
55.2\end{array}$ & $\begin{array}{l}39.5 \\
65.3\end{array}$ & $\begin{array}{l}\text { BSEQ } \\
\text { CHEM } \\
\text { CONS } \\
\text { METL }\end{array}$ & $\begin{array}{r}12.1 \\
4.7 \\
5.0 \\
1.7\end{array}$ & $\begin{array}{r}23.3 \\
8.6 \\
9.5 \\
5.2\end{array}$ & $\begin{array}{l}38.6 \\
37.0 \\
37.9 \\
60.0\end{array}$ \\
\hline \multicolumn{9}{|c|}{ Five-Year Forecasts } \\
\hline 1982 & UTIL & 17.2 & 68.0 & 79.1 & $\begin{array}{l}\text { BSEQ } \\
\text { DURA } \\
\text { OIL }\end{array}$ & $\begin{array}{r}12.8 \\
6.9 \\
6.3\end{array}$ & $\begin{array}{l}21.1 \\
11.7 \\
12.5\end{array}$ & $\begin{array}{l}32.9 \\
34.1 \\
40.0\end{array}$ \\
\hline 1983 & $\begin{array}{l}\text { MINE } \\
\text { UTIL }\end{array}$ & $\begin{array}{r}2.1 \\
15.7\end{array}$ & $\begin{array}{r}4.4 \\
62.5\end{array}$ & $\begin{array}{l}42.9 \\
79.4\end{array}$ & $\begin{array}{l}\text { BSEQ } \\
\text { DURA } \\
\text { MISC }\end{array}$ & $\begin{array}{r}13.4 \\
7.1 \\
11.2\end{array}$ & $\begin{array}{l}22.8 \\
13.2 \\
17.6\end{array}$ & $\begin{array}{l}34.1 \\
37.5 \\
31.6\end{array}$ \\
\hline 1984 & UTIL & 16.3 & 69.1 & 84.7 & $\begin{array}{l}\text { BSEQ } \\
\text { DURA } \\
\text { MISC } \\
\text { RETA }\end{array}$ & $\begin{array}{r}13.1 \\
7.1 \\
10.6 \\
2.6\end{array}$ & $\begin{array}{r}24.3 \\
12.5 \\
16.9 \\
5.1\end{array}$ & $\begin{array}{l}37.1 \\
35.4 \\
31.9 \\
38.9\end{array}$ \\
\hline
\end{tabular}

Note: The industry abbreviations are: $\mathrm{APPA}=$ Apparel; $\mathrm{AUTO}=$ Automobile; $\mathrm{BSEQ}=$ Business Equipment; $\quad \mathrm{CHEM}=$ Chemical; $\quad \mathrm{CONS}=$ Construction; $\quad \mathrm{DURA}=$ Durables; $F I N A=$ Financial; METL $=$ Metal; $\quad$ MINE $=$ Mining; $\quad$ MISC $=$ Miscellaneous; $\quad$ OIL $=$ Petroleum; $\quad$ RETA $=$ Retail; TRAN = Transportation; UTIL $=$ Utilities. Companies are classified into industries as in Fama and French (1988),

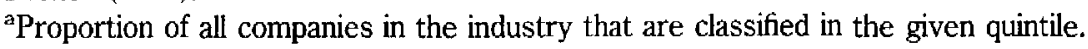

more than 20 percent of the companies belong to the quintile. ${ }^{6}$ Several cyclical industries shift back and forth between the extreme quintiles, most notably automobiles, mining, metals, chemicals, and petroleum. Other companies, such

${ }^{6}$ For each year, I also computed multinomial $\chi^{2}$ tests to check whether 10 percent of the firms in each industry end up in each earnings-growth decile. With 18 industries and 21 yearly samples, $378 \chi^{2}$ s were computed. Eighty-one are significant at the 5 percent level. 
TABLE 4. Statistics for Quintile Portfolios (\$millions, except as noted)

\begin{tabular}{|c|c|c|c|c|c|c|c|c|}
\hline \multirow[b]{2}{*}{ Portfolio } & \multicolumn{2}{|c|}{ Assets } & \multicolumn{2}{|c|}{ Market Value } & \multicolumn{2}{|c|}{ Income } & \multirow{2}{*}{$\begin{array}{l}\text { Market- } \\
\text { to-Book }\end{array}$} & \multirow{2}{*}{$\begin{array}{c}\text { Number of } \\
\text { Analysts }\end{array}$} \\
\hline & Mean & Median & Mean & Median & Mean & Median & & \\
\hline
\end{tabular}

One-Year Forecasts

$\begin{array}{lrrrrrrrr}\text { Q1 } & \$ 2,794 & \$ 1,012 & \$ 809 & \$ 319 & \$ 127.0 & \$ 50.5 & 0.95 & 6.2 \\ \text { Q2 } & 3,564 & 969 & 1,088 & 368 & 130.1 & 47.0 & 1.18 & 7.1 \\ \text { Q3 } & 2,741 & 831 & 1,266 & 443 & 125.1 & 45.8 & 1.53 & 8.1 \\ \text { Q4 } & 2,337 & 709 & 1,106 & 393 & 98.6 & 38.5 & 1.52 & 7.4 \\ \text { Q5 } & 2,221 & 639 & 757 & 285 & 63.5 & 21.0 & 1.29 & 5.6\end{array}$

Two-Year Forecasts

$\begin{array}{lrrrrrrrr}\text { Q1 } & \$ 4,025 & \$ 1,707 & \$ 1,508 & \$ 604 & \$ 232.6 & \$ 87.6 & 1.07 & 11.2 \\ \text { Q2 } & 3,296 & 1,540 & 1,890 & 700 & 195.9 & 86.6 & 1.42 & 10.8 \\ \text { Q3 } & 3,967 & 1,284 & 1,745 & 751 & 184.8 & 79.4 & 1.68 & 11.6 \\ \text { Q4 } & 3,296 & 1,060 & 1,907 & 656 & 146.6 & 60.7 & 1.83 & 11.1 \\ \text { Q5 } & 3,026 & 956 & 1,241 & 498 & 103.4 & 37.9 & 1.50 & 9.8\end{array}$

Five-Year Forecasts

$\begin{array}{lrrrrrrrr}\text { Q1 } & \$ 2,958 & \$ 1,370 & \$ 747 & \$ 378 & \$ 116.3 & \$ 53.0 & 0.90 & 8.7 \\ \text { Q2 } & 7,285 & 2,081 & 1,293 & 587 & 201.6 & 61.9 & 0.92 & 10.7 \\ \text { Q3 } & 4,422 & 1,083 & 1,267 & 564 & 154.6 & 55.4 & 1.24 & 11.3 \\ \text { Q4 } & 2,170 & 768 & 1,399 & 484 & 121.3 & 34.8 & 1.51 & 10.7 \\ \text { Q5 } & 1,904 & 311 & 860 & 253 & 51.3 & 15.5 & 1.98 & 8.0\end{array}$

Note: Assets, market value, and corporate income are measured for year $t-1$. Means are averages of yearly averages. Medians are averages of yearly medians. The market-to-book value of equity ratio is at the end of year $t-1$. The number of analysts is the average number of analysts who provide one-year earnings forecasts in year $t$.

as drugs or food, never appear. After 1980, pessimism with respect to utilities clearly shows in the samples, especially for the five-year forecasts.

Table 4 describes the size of the firms in the samples. Assets, market value, and company income are all measured at the end of year $t-1$. The companies are generally very large, although they are somewhat less so for the quintile for which analysts were most optimistic (Q5). On average, fewer analysts followed these firms. 


\section{Are Market Forecasts of Earnings Growth Too Extreme?}

This chapter discusses overreaction by analysts as well as market overreaction to earnings. If even professionals are subject to systematic bias, then the case for market overreaction becomes more convincing.

\section{Overreaction by Analysts}

Table 5 repeats the rationality tests of De Bondt and Thaler (1990) for vitile projected earnings-growth portfolios. The regression took the form $A C=\alpha+$ $\beta F C$, where $A C$ is the normalized actual earnings change and $F C$ is the predicted change. Under rational expectations, $(\alpha, \beta)=(0,1)$. Overreaction predicts that $\beta<1$. For comparison, Table 5 also includes the results found for individual companies in De Bondt and Thaler. ${ }^{7}$

Table 5 leaves little doubt that forecast errors grow with the size of the forecasted changes, as well as with the forecast horizon. It is this feature of the data that suggests that an indiscriminate "bias toward optimism" does not adequately describe analyst errors. ${ }^{8}$ Figures 3 and 4 provide illustrations of analyst overoptimism. Because the forecasted changes are normalized, errors of different (absolute) magnitudes are unlikely to represent similar percentage size errors. Note that there are few forecasts of earnings decreases. This

${ }^{7}$ I do not have sufficient earnings data to evaluate the quality of the five-year forecasts. Consequently, the rationality tests for these forecasts are missing in Table 5.

${ }^{8}$ This is not to deny the relevance of optimism bias. Such bias is clearly supported by the statistical significance of the intercepts in the regression and by the earlier tests of O'Brien (1988). But optimism bias does not tell the whole story. 


\section{TABLE 5. Tests for the Rationality of Earnings-Per-Share Forecasts}

\begin{tabular}{lll}
\hline Variables & $\alpha^{\mathrm{a}}$ & $\beta^{\mathrm{b}}$ \\
\hline
\end{tabular}

Vitile Portfolios

\begin{tabular}{llll}
$\mathrm{AC} 1, \mathrm{FC} 1$ & $-0.431(-3.6)$ & $0.617(-6.4)$ & 0.85 \\
$\mathrm{AC} 2, \mathrm{FC} 2$ & $0.261(-3.1)$ & $0.528(-11.2)$ & 0.90 \\
& & & \\
Individual Companies $^{\mathrm{c}}$ & & & \\
$\mathrm{AC} 1, \mathrm{FC} 1$ & $-0.094(-3.7)$ & $0.648(-21.7)$ & 0.22 \\
$\mathrm{AC} 2, \mathrm{FC} 2$ & $-0.137(-2.3)$ & $0.459(-19.5)$ & 0.07 \\
\hline
\end{tabular}

Note: $\mathrm{AC} 1, \mathrm{AC} 2=$ Actual changes in EPS, one- and two-year horizons; $\mathrm{FC} 1, \mathrm{FC} 2=$ Forecasted changes in EPS, one- and two-year horizons.

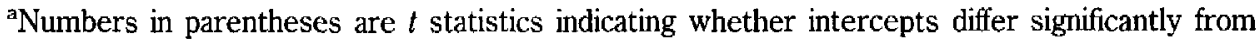
zero.

'Numbers in parentheses are $t$ statistics indicating whether slopes differ significantly from 1 .

cFrom De Bondt and Thaler (1990).

probably reflects the inflationary climate of the late 1970 s. For EPS to fall in nominal terms, a very large decline in real terms must be projected. The fact that actual decreases are even larger than predicted decreases may reflect optimism bias. The results for decreases appear to be inconsistent with overreaction. Nevertheless, the weight of the evidence favors overreaction.

What causes excessive pessimism or optimism? This is a difficult question. Klein (1990) considers past stock price performance a possible candidate. Analysts do not underpredict EPS following large price declines. ${ }^{9}$ Klein concludes that the "cognitive bias theory" of share price reversals is not supported (p. 156), but this conclusion is hasty. First, it is built on the monumental assumption that the average investor is as sophisticated as the average security analyst. Surely, market expectations may show too much pessimism after a large price fall, even if the forecasts of experts do not. Second, stock prices are a poor indicator of whether traders overreact to one specific set of information, because prices aggregate news about many different factors. Klein's logic runs from the general to the specific. Her premise-that "the cognitive bias theory predicts overly optimistic (pessimistic) earnings

${ }^{9}$ Analyst expectations are on average too high for past winner stocks, and the average subsequent forecast revision is "down." Also, for past losers, the optimism bias becomes less extreme. Both observations are consistent with overreaction. I thank Joshua Ronen for this insight. 


\section{FIGURE 3. Actual and Predicted One-Year Earnings Changes}

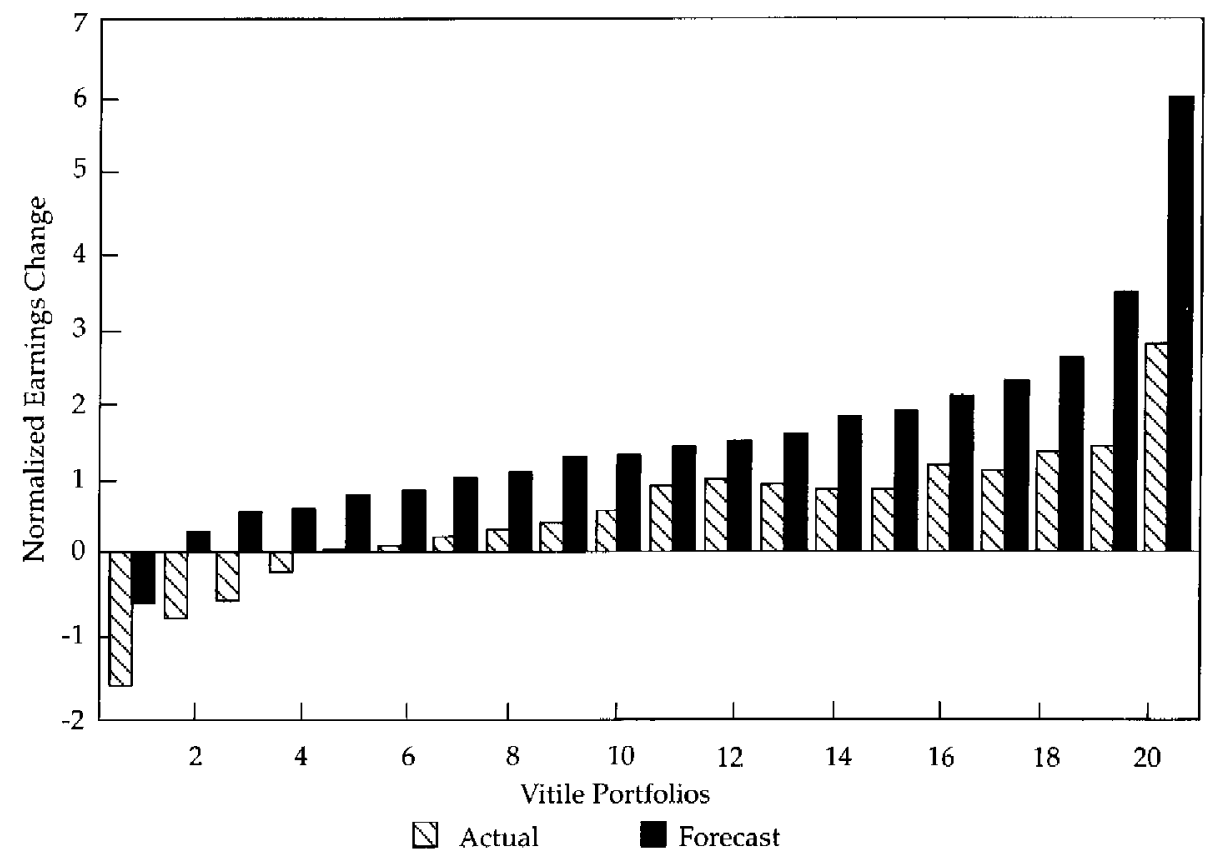

expectations [by analysts] for firms that just experienced extremely good (bad) returns"-is simply not true. The overreaction hypothesis is about the determination of share prices in markets, not the beliefs of groups of traders. Without listing its specific causes, past two- to five-year returns can serve as a proxy for the level of (partly justified) "investor excitement." The theory then predicts price reversals (see De Bondt and Thaler 1985). With respect to specific news items, overreaction predicts that if an important group of investors, such as analysts, overreacts, then share prices are likely to reflect the same bias. This is the hypothesis tested in this study.

Analyst overreaction may also be explained by the time-series pattern of company earnings. To get some idea of how actual earnings movements vary through time in comparisons of firms for which analysts have very different growth expectations, the following method was used. The basic data are annual earnings for every firm (before extraordinary items and discontinued operations) for years $t-5$ to $t+1$, where $t$ is the year of the April forecast. The 


\section{FIGURE 4. Actual and Predicted Two-Year Earnings Changes}

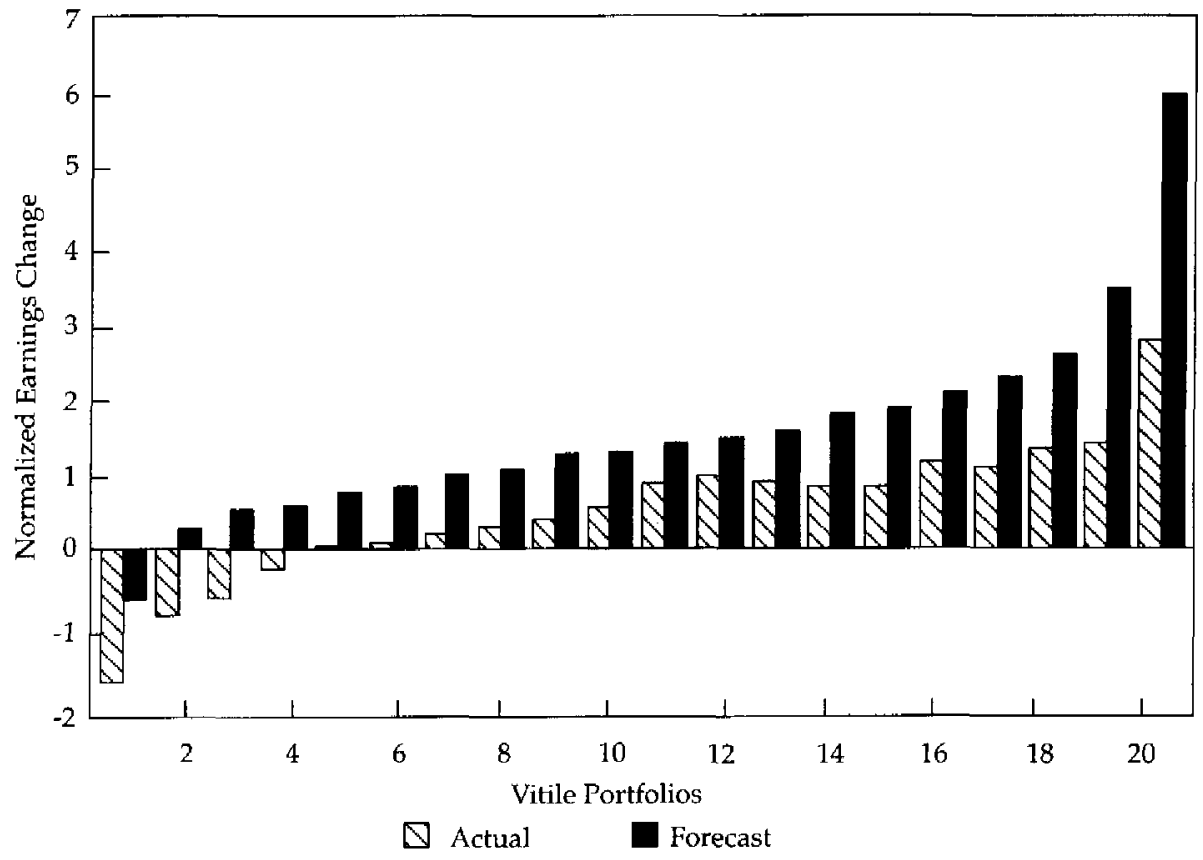

earnings numbers are normalized by the market value of equity at the end of year $t-1$. Then, an equally weighted average of the earnings of all companies $E_{s, t}$ was found for each yearly sample $s,(s=1, \ldots, S)$ and for each year, $t$. A simple earnings index $I_{s, t}$ is $\Sigma\left(\mathrm{E}_{s, t} / \mathrm{E}_{s, t-5}\right)(100)$, where $t-5$ is the base year. Portfolio indexes similar to $I_{s, t}$ were computed for earnings-growth quintiles. These indexes are denoted $Q x_{s, t}$, where $x=1, \ldots, 5$. To purge from $Q x_{s, t}$ the component in earnings growth that is common to all companies, a second index was calculated, $Q x^{*}{ }_{s t}=\left(Q x_{s, t} / I_{s, t}\right)(100)$. Finally, the quintile indexes were averaged across the yearly samples so that $Q x^{a}{ }_{t}=(1 / S) \Sigma Q x^{*}{ }_{s, t}$. By construction, $Q x^{a}{ }_{t-5}$ is 100.

Table 6 lists $Q 1^{a}{ }_{t} \ldots Q 5^{a}{ }_{t}$, as well as similar indexes for the extreme decile portfolios. For the one- and two-year forecasts, the evidence not only supports the view that security analysts recognize mean reversion in earnings but, in fact, suggests that the analysts overadjust for the mean reversion. The companies for which the analysts are too pessimistic (Q1) experienced a large 
TABLE 6. Indexes of Actual Earnings Movements for Projected Earnings Growth Portfolios

\begin{tabular}{|c|c|c|c|c|c|c|c|}
\hline \multirow[b]{2}{*}{ Portfolio } & \multicolumn{7}{|c|}{ Year } \\
\hline & $(t-5)$ & $(t-4)$ & $(t-3)$ & $(t-2)$ & $(t-1)$ & $(t)^{\mathrm{a}}$ & $(t+1)$ \\
\hline \multicolumn{8}{|c|}{ One-Year Forecasts } \\
\hline D1 & 100.0 & 104.8 & 108.2 & 125.9 & 150.8 & 112.1 & 100.6 \\
\hline Q1 & 100.0 & 96.9 & 103.9 & 105.6 & 134.0 & 105.6 & 97.3 \\
\hline Q2 & 100.0 & 99.2 & 99.4 & 108.2 & 111.7 & 104.0 & 101.0 \\
\hline Q3 & 100.0 & 99.0 & 100.0 & 100.2 & 104.6 & 102.9 & 103.6 \\
\hline Q4 & 100.0 & 100.5 & 96.8 & 101.2 & 100.0 & 104.9 & 108.7 \\
\hline Q5 & 100.0 & 104.4 & 99.8 & 86.1 & 52.9 & 84.4 & 91.4 \\
\hline D10 & 100.0 & 105.1 & 102.5 & 86.6 & 31.9 & 74.3 & 83.5 \\
\hline \multicolumn{8}{|c|}{ Two-Year Forecasts } \\
\hline D1 & 100.0 & 97.0 & 97.5 & 130.3 & 135.4 & 98.6 & 88.9 \\
\hline Q1 & 100.0 & 93.3 & 96.9 & 97,6 & 120.0 & 100.8 & 92.5 \\
\hline Q2 & 100.0 & 100.0 & 100.6 & 109.9 & 108.8 & 103.6 & 103.0 \\
\hline Q3 & 100.0 & 102.2 & 102.4 & 103.1 & 103.3 & 101.2 & 101.8 \\
\hline $\mathrm{Q} 4$ & 100.0 & 106.2 & 106.1 & 100.0 & 94.4 & 107.8 & 110.2 \\
\hline Q5 & 100.0 & 100.7 & 96.4 & 91.8 & 71.6 & 88.3 & 95.9 \\
\hline D10 & 100.0 & 96.9 & 94.3 & 88.6 & 65.4 & 87.7 & 91.9 \\
\hline \multicolumn{8}{|c|}{ Five-Year Forecasts } \\
\hline D1 & 100.0 & 102.4 & 107.3 & 97.8 & 100.1 & 118.0 & 133.9 \\
\hline Q1 & 100.0 & 104.1 & 103.3 & 96.9 & 90.0 & 101.3 & 115.2 \\
\hline Q2 & 100.0 & 96.3 & 100.4 & 96.0 & 87.3 & 85.5 & 75.3 \\
\hline Q3 & 100.0 & 100.4 & 96.1 & 97.4 & 97.2 & 92.2 & 92.3 \\
\hline Q4 & 100.0 & 102.9 & 101.8 & 105.1 & 105.4 & 101.0 & 107.6 \\
\hline Q5 & 100.0 & 96.4 & 99.3 & 103.6 & 117.8 & 120.6 & 110.9 \\
\hline D10 & 100.0 & 92.8 & 89.6 & 89.8 & 116.0 & 127.3 & 110.4 \\
\hline
\end{tabular}

aYear of the earnings forecast.

positive (firm-specific) earnings shock in year $t-1$. In contrast, the companies for which they are too optimistic experienced a negative shock. ${ }^{10}$

\footnotetext{
${ }^{10}$ Thus, earnings move in a pattern that is quite different from the typical earnings pattern for stock market winners and losers (see De Bondt and Thaler 1987). Zarowin (1989) shows that by forming portfolios of companies characterized by extremely good or bad current earnings (relative to historical experience), excess returns can be earned. The tests are motivated by overreaction. Market participants may bid up the stock prices of the good earnings performers too high and bid down the prices of the bad performers too low (Zarowin attributes the abnormal performance to the fact that the poorest earners in his sample are significantly smaller than the best earners), Note that here, by ranking on earnings expectations (rather than earnings shocks), I obtain the exact opposite result. As it turns out, Q1 beats Q5 in the stock market. Also, I attribute too much investor pessimism to the companies (Q1) for which Zarowin expects too much optimism, and the reverse for $\mathrm{Q} 5$.
} 


\section{TABLE 7. Cumulative Excess Returns for Arbitrage Portfolios that Exploit Unrealistic Forecasts of Earnings Growth, Test Period}

\begin{tabular}{|c|c|c|c|c|c|c|}
\hline \multirow[b]{2}{*}{ Month } & \multicolumn{2}{|c|}{ Market-Adjusted } & \multicolumn{2}{|c|}{ Industry-Adjusted } & \multicolumn{2}{|c|}{ Size-Adjusted } \\
\hline & $\mathrm{CX}_{\mathrm{p}}-\mathrm{CX}_{\mathrm{o}}$ & $\rho_{X}$ & $\mathrm{CI}_{\mathrm{p}}-\mathrm{CI}_{\mathrm{o}}$ & $\rho_{\mathrm{I}}$ & $\mathrm{CS}_{\mathrm{p}}-\mathrm{CS}_{\mathrm{o}}$ & $\rho_{\mathrm{S}}$ \\
\hline
\end{tabular}

One-Year Forecasts

$\begin{array}{rllllll}1 & 0.75 & -0.49^{* *} & 0.52 & -0.47^{* * *} & 0.83 & -0.62^{* * * *} \\ 3 & 1.24 & -0.65^{* * *} & 0.95 & -0.43 & 1.28 & -0.62^{* * *} \\ 6 & 1.78 & -0.44 & 1.43 & -0.31 & 1.66 & -0.43 \\ 9 & 2.38 & -0.43 & 2.25 & -0.50^{* *} & 2.34 & -0.42 \\ 12 & 3.44 & -0.52^{* *} & 2.50 & -0.48^{* *} & 3.30 & -0.53^{* *} \\ 15 & 2.81 & -0.42 & 2.53 & -0.45^{* *} & 2.64 & -0.43 \\ 18 & 4.27 & -0.51^{* *} & 3.93 & -0.52^{* *} & 3.88 & -0.50^{* *} \\ 21 & 4.26 & -0.52^{* *} & 3.68 & -0.54^{* *} & 4.00 & -0.56^{* *}\end{array}$

Two-Year Forecasts

$\begin{array}{rllllll}1 & 1.15 & -0.43 & 0.47 & -0.13 & 1.27 & -0.51^{* *} \\ 3 & 2.32 & -0.50^{* *} & 1.38 & -0.43 & 2.49 & -0.48^{* *} \\ 6 & 2.89 & -0.61^{* * *} & 1.98 & -0.38 & 2.82 & -0.58^{* * *} \\ 9 & 3.68 & -0.74^{* * *} & 3.25 & -0.60^{* * *} & 3.85 & -0.67^{* * *} \\ 12 & 5.26 & -0.84^{* * *} & 4.00 & -0.63^{* * *} & 5.29 & -0.84^{* * *} \\ 15 & 5.57 & -0.74^{* * *} & 4.82 & -0.47^{* *} & 5.52 & -0.71^{* * *} \\ 18 & 6.58 & -0.58^{* * *} & 5.96 & -0.48^{* *} & 6.16 & -0.54^{* *} \\ 21 & 6.04 & -0.59^{* * *} & 5.86 & -0.41 & 5.85 & -0.58^{* * *}\end{array}$

Five-Year Forecasts

$\begin{array}{rrlrlrl}1 & 2.47 & -0.36 & 0.51 & -0.19 & 2.55 & -0.42 \\ 3 & 1.70 & -0.18 & 0.60 & -0.08 & 1.80 & -0.16 \\ 6 & 3.96 & -0.55^{* *} & 1.53 & -0.24 & 3.80 & -0.52^{* *} \\ 9 & 1.00 & -0.21 & 1.52 & -0.20 & 1.01 & -0.17 \\ 12 & 5.51 & -0.59^{* * *} & 4.52 & -0.45^{* *} & 5.69 & -0.56^{* *} \\ 15 & 5.29 & -0.57^{* * *} & 5.49 & -0.53^{* *} & 5.29 & -0.51^{* *} \\ 18 & 15.19 & -0.78^{* * *} & 9.34 & -0.48^{* *} & 15.02 & -0.74^{* * *} \\ 21 & 11.91 & -0.69^{* * *} & 9.04 & -0.56^{* *} & 11.85 & -0.68^{* * *}\end{array}$

Note: $\mathrm{CX}_{\mathrm{p}}$ is the cumulative market-adjusted excess return (CAR) for the quintile of companies for which the analysts are most pessimistic (Q1). CX $\mathrm{C}_{\mathrm{o}}$ is the CAR for the quintile of companies for which the analysts are most optimistic (Q5). $\mathrm{CI}_{\mathrm{o}}$ and $\mathrm{CI}_{\mathrm{p}}$ are the CARs with industry-adjusted excess returns. $\mathrm{CS}_{\mathrm{o}}$ and $\mathrm{CS}_{\mathrm{p}}$ are the CARs with size-adjusted excess returns. Spearman correlations are calculated for vitile portfolios. The correlations marked ${ }^{* *}$ are significant at the 5 percent level, and those marked $* * *$ are significant at the 1 percent level. 


\section{TABLE 8. Cumulative Excess Returns for Extreme Quintile and Arbitrage Portfolios that Exploit Unrealistic Forecasts of Earnings Growth, Test Period}

\begin{tabular}{|c|c|c|c|c|c|c|c|c|}
\hline Month & $\mathrm{CX}_{\mathrm{p}}$ & $t$ & $\mathrm{CX}_{\mathrm{o}}$ & $t$ & $\mathrm{CX}_{\mathrm{p}}-\mathrm{CX}_{\mathrm{o}}$ & $t_{X}$ & $t_{I}$ & $t_{\mathrm{s}}$ \\
\hline \multicolumn{9}{|c|}{ One-Year Forecasts } \\
\hline 12 & 1.38 & 0.90 & -2.06 & $-3.90^{* * * *}$ & 3.44 & $2.04^{* * *}$ & $1.39^{*}$ & $1.81^{*}$ \\
\hline 15 & 0.90 & 0.53 & -1.91 & $-1.83^{* *}$ & 2.81 & 1.20 & $1.38^{*}$ & 1.09 \\
\hline 18 & 0.40 & 0.21 & -3.87 & $-2.27^{* *}$ & 4.27 & $1.87^{* *}$ & $2.02^{* *}$ & $1.63^{*}$ \\
\hline 21 & 0.87 & 0.46 & -3.39 & $-1.79^{* * *}$ & 4.26 & $1.80^{* * *}$ & $1.74^{* *}$ & $1.66^{*}$ \\
\hline \multicolumn{9}{|c|}{ Two-Year Forecasts } \\
\hline 12 & 2.60 & 1.25 & -2.67 & -1.22 & 5.26 & 1.21 & 1.19 & 1.21 \\
\hline 15 & 2.01 & 0.83 & -3.56 & $-1.63^{*}$ & 5.57 & 1.26 & $1,40^{*}$ & 1.24 \\
\hline 18 & 1.46 & 0.58 & -5.12 & $-2.19 * *$ & 6.58 & $1.50 \%$ & $1.76^{* * *}$ & $1.41^{*}$ \\
\hline 21 & 1.36 & 0.48 & -4.68 & $-1.83^{* *}$ & 6.04 & 1.19 & $1.54^{*}$ & 1.13 \\
\hline
\end{tabular}

Five-Year Forecasts

\begin{tabular}{rrrrlrlll}
12 & 0.95 & 0.24 & -4.55 & -1.32 & 5.51 & 0.82 & $1.48^{*}$ & .87 \\
15 & 1.23 & 0.30 & -4.06 & -1.08 & 5.29 & 0.74 & $1.61^{*}$ & .75 \\
18 & 5.25 & 1.08 & -9.94 & $-2.05^{* *}$ & 15.19 & $1.67^{*}$ & $2.38^{* *}$ & $1.68^{*}$ \\
21 & 3.62 & 0.70 & -8.29 & $-1.61^{*}$ & 11.91 & 1.24 & $2.24^{* *}$ & 1.25 \\
\hline
\end{tabular}

Note: $\mathrm{CX}_{\mathrm{p}}$ is the average cumulative excess return (CAR) for the quintile of companies for which the analysts are most pessimistic (Q1). $\mathrm{CX}_{\mathrm{o}}$ is the CAR for the quintile of companies for which the analysts are most optimistic (Q5). For the arbitrage portfolio $\left(\mathrm{CX}_{\mathrm{p}}-\mathrm{CX}_{\mathrm{o}}\right)$ the $t$-statistics are based on market-adjusted $\left(t_{X}\right)$, industry-adjusted $\left(t_{I}\right)$, and size-adjusted $\left(t_{S}\right)$ excess returns. $t$-statistics marked ${ }^{*}$ are significant at the 10 percent level, those marked ${ }^{* *}$ are significant at the 5 percent level, and those marked $* * *$ are significant at the 1 percent level.

The results for the five-year forecasts are less puzzling. They look like those of De Bondt and Thaler (1987). The analysts are pessimistic for firms that show an apparent downward trend in earnings. The trend reverses itself in years $t$ and $t+1$. Companies for which analysts are optimistic saw a rise in profits during previous years. Again, the tide turns in year $t+1$.

\section{Market Overreaction}

Do stock prices reflect excessive investor optimism or pessimism about future earnings? Tables 7,8 , and 9 present the cumulative excess returns earned by the extreme projected earnings growth portfolios. Table 7 reports results for vitile portfolios as well as for an imaginary arbitrage portfolio that buys companies in the first quintile (Q1) and sells companies in Q5. This 
TABLE 9. Cumulative Excess Returns for Quintile Portfolios of Companies with High/Low Projected Earnings Growth, Test Period

\begin{tabular}{|c|c|c|c|c|c|c|}
\hline \multirow[b]{2}{*}{ Month } & \multicolumn{2}{|c|}{ One-Year Forecasts } & \multicolumn{2}{|c|}{ Two-Year Forecasts } & \multicolumn{2}{|c|}{ Five-Year Forecasts } \\
\hline & $\mathrm{CX}_{\mathrm{o}}$ & $C X_{p}$ & $\mathrm{CX}_{\mathrm{o}}$ & $C X_{p}$ & $\mathrm{CX}_{\mathrm{o}}$ & $\mathrm{CX}_{\mathrm{p}}$ \\
\hline 1 & -0.09 & 0.66 & -0.44 & 0.72 & -0.26 & 2.21 \\
\hline 2 & -0.22 & 0.68 & -0.94 & 0.92 & 1.04 & 0.39 \\
\hline 3 & -0.49 & 0.76 & -0.99 & 1.32 & 0.16 & 1.86 \\
\hline 4 & -0.67 & 0.95 & -1.33 & 1.50 & 0.46 & 0.84 \\
\hline 5 & -1.26 & 0.69 & -2.17 & 1.95 & -1.32 & 2.01 \\
\hline 6 & -1.56 & 0.22 & -1.62 & 1.27 & -1.95 & 2.01 \\
\hline 7 & -0.98 & 0.10 & -0.80 & 0.91 & -2.06 & 1.33 \\
\hline 8 & -1.42 & 0.13 & -0.99 & 0.69 & -1.62 & 0.74 \\
\hline 9 & -1.25 & 1.13 & -1.64 & 2.04 & -0.75 & 0.25 \\
\hline 10 & -1.55 & 1.26 & -2.54 & 2.50 & -1.83 & 0.83 \\
\hline 11 & -1.75 & 1.62 & -2.79 & 3.12 & -3.74 & 1.20 \\
\hline 12 & -2.06 & 1.38 & -2.67 & 2.60 & -4.55 & 0.95 \\
\hline 13 & -2.47 & 1.60 & -3.18 & 2.45 & -4.50 & 1.63 \\
\hline 14 & -2.36 & 1.34 & -3.69 & 1.99 & -3.36 & 0.69 \\
\hline 15 & -1.91 & 0.90 & -3.56 & 2.01 & -4.06 & 1.23 \\
\hline 16 & -2.22 & 1.30 & -3.70 & 1.96 & -4.95 & 1.42 \\
\hline 17 & -3.08 & 1.21 & -4.74 & 2.28 & -7.31 & 2.84 \\
\hline 18 & -3.87 & 0.40 & -5.12 & 1.46 & -9.94 & 5.25 \\
\hline 19 & -3.90 & 0.47 & -4.34 & 0.99 & -9.53 & 4.00 \\
\hline 20 & -3.91 & 0.48 & -4.47 & 0.61 & -9.06 & 3.23 \\
\hline 21 & -3.39 & 0.87 & -4.68 & 1.36 & -8.29 & 3.62 \\
\hline
\end{tabular}

Note: $\mathrm{CX}_{\mathrm{p}}$ is the average cumulative excess return (CAR) for the quintile of companies for which the analysts are most pessimistic (Q1). $\mathrm{CX}_{\mathrm{o}}$ is the CAR for the quintile of companies for which the analysts are most optimistic (Q5). The excess returns are adjusted for movements in the market portfolio.

arbitrage portfolio contains 40 percent of all companies in the sample. The findings are based on market-, industry- and size-adjusted excess returns.

The return on the market portfolio is defined as the mean return earned by all companies in the sample. Additional return indexes are needed to calculate industry- and size-adjusted excess returns. All firms that meet the requirements (steps 1 through 4 in Chapter 2) can enter any of the samples. The returns by company size are equally weighted averages of the returns earned by all firms in a given market-value decile. Market value is measured at the end of the previous calendar year, and the portfolios are rebalanced each year. The returns by industry are equally weighted averages of the monthly stock returns 
earned by all companies in a given industry. Industries are defined as in Fama and French (1988). To make sure that the industry returns are reliable, they are only calculated for industries that have at least 15 listed stocks in the sample each month between April 1973 and January 1986. This method eliminates apparel, automobile, food, metal, metal products, mining, and retail companies. The 10 industries with the most firms are left.

The overreaction-to-earnings hypothesis predicts an inverse relationship between projected earnings growth and subsequent returns, which the data strongly confirm. Table 7 presents Spearman rank correlations between both variables for vitile portfolios. In all cases, the correlations are negative, and in most, they are statistically significant.

The overreaction-to-earnings hypothesis further predicts that portfolio Q1 outperforms Q5. Table 7 shows that this appears to be the case, whichever way the excess returns are calculated.11 The significance tests (which follow Rendleman et al. 1982) are less convincing than one would like, as Table 8 indicates. Remember, however, that the arbitrage portfolio contains fully 40 percent of all companies in the sample. Eighteen months after the forecast month, the abnormal performance of the arbitrage portfolio is near its maximum. One can state with more confidence that Q5 underperforms the averages than that Q1 outperforms them (see also Table 9). This is confirmed by the return patterns of the extreme decile and vitile portfolios (not reported). ${ }^{12}$

\footnotetext{
${ }^{11}$ This is important for two reasons. First, Chapter 2 shows that some industries are disproportionately represented in the extreme portfolios. For the sake of argument, assume that one of the extreme earnings-growth portfolios contains companies of only a single industry and that, indeed, all firms in that industry belong to the portfolio. Then, the use of industry-adjusted excess returns sets CAR equal to zero and the tests are conservative--that is, biased toward rejection of market overreaction.

Second, it is important that the results survive the use of size-adjusted returns because there is a significant size effect in this sample. I use the methods of Ball and Kothari (1989), with monthly returns, to isolate the size effect. See Chapter 4 for a full explanation. On average, over the first 12 months after the forecast month, the quintile of the smallest firms outperforms the quintile of the largest firms by 0.466 percent a month $(t=2.64)$. The excess returns (Jensen's alphas) take into account the higher CAPM betas $(1.10$ vs. 0.90$)$ of the smaller companies. Because analysts are more optimistic about the earnings prospects of small firms, the size effect biases the market-adjusted CAR against market overreaction.

${ }^{12}$ On Wall Street, stocks with high EPS growth expectations are sometimes referred to as "torpedo stocks" because of their much feared propensity "to sink the portfolio." The results in Tables 8 and 9 are consistent with the torpedo effect, a phenomenon also previously examined (in unpublished studies) by Robert Hagin. I thank Dan Coggin for bringing Hagin's interesting work to my attention.
} 


\section{FIGURE 5. Test Period Returns for Arbitrage Portfolios}

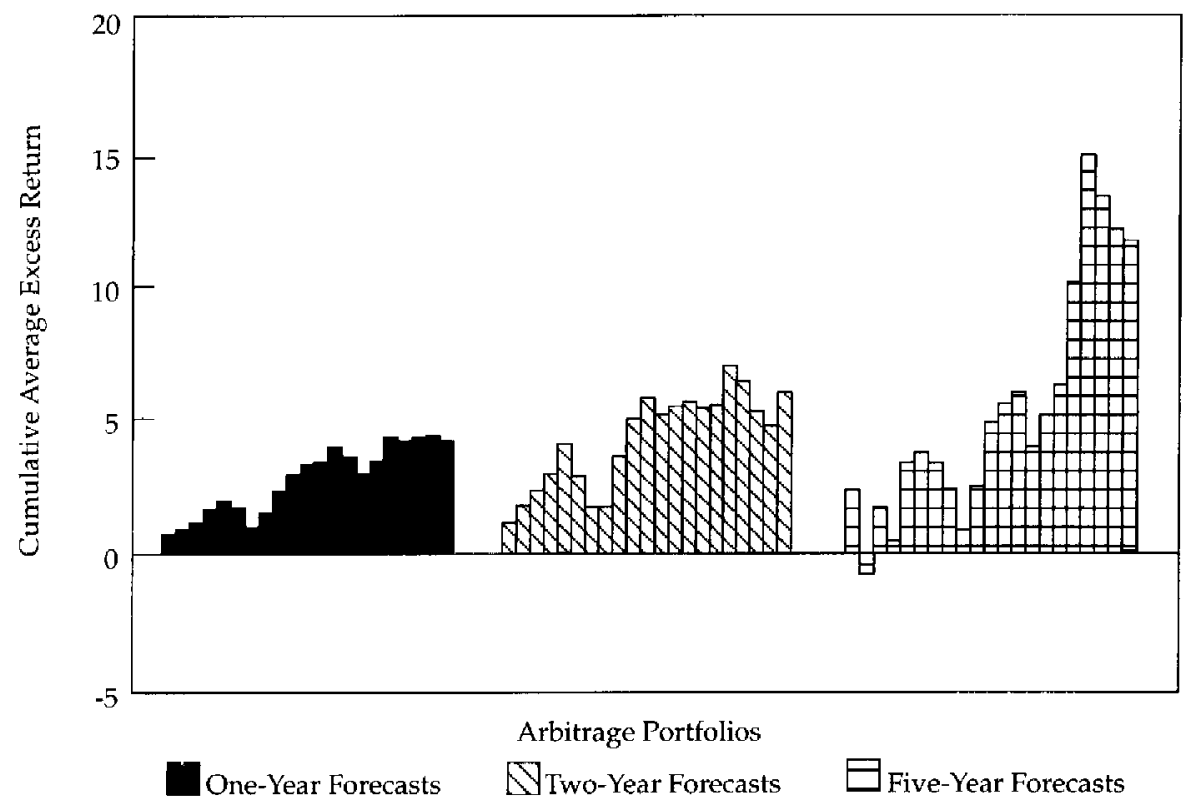

Consistent with overreaction, the CARs are larger for longer term forecasts, as is apparent in Figure 5, which plots the test period market-adjusted CARs of the different arbitrage portfolios. The inverse relationship with expected earnings growth is also more reliable for longer term forecasts. In Table 7, the Spearman rank correlations grow with the forecast horizon. Table 10 makes the same point in a slightly different way, with regressions of CAR on the rank of the earnings-growth vitile portfolios for both the initial 36-month rank period and the subsequent 21-month test period (see Chapter 2). The (absolute) magnitude of the slope coefficients, the associated $t$ statistics, and the adjusted $R^{2} \mathrm{~s}$ all increase with forecast horizon. Again, how the excess returns are measured does not matter.

How do all the previous results relate to the winner-loser effect? ${ }^{13}$ One way

\footnotetext{
${ }^{13}$ For the $1926-82$ period, portfolios of extreme stock market losers (formed on the basis of prior five-year returns) subsequently outperformed extreme winners by about 8 percent annually for the next five years (see De Bondt and Thaler 1985).
} 
TABLE 10. Regressions of Cumulative Excess Returns on Projected Earnings Growth, Rank and Test Periods

\begin{tabular}{|c|c|c|c|c|c|c|c|c|c|}
\hline \multirow[b]{2}{*}{ Dependent Variable } & \multicolumn{3}{|c|}{ Market-Adjusted } & \multicolumn{3}{|c|}{ Industry-Adjusted } & \multicolumn{3}{|c|}{ Size-Adjusted } \\
\hline & $\beta^{\mathrm{M}}$ & $\mathrm{t}_{\beta}$ & $\mathrm{R}^{2}$ & $\beta^{I}$ & $t_{\beta}$ & $\mathrm{R}^{2}$ & $\beta^{S}$ & $t_{\beta}$ & $\mathrm{R}^{2}$ \\
\hline
\end{tabular}

One-Year Forecasts

CAR (rank period)

$0.23 \quad 1.8$

$\begin{array}{lll}0.11 & 0.32 & 2.0\end{array}$

$0.14 \quad 0.23 \quad 1.6$

0.08

CAR (test period)

$-0.27-2.6$

$0.23-0.22-2.7$

$\begin{array}{llll}0.24 & -0.28 & -2.9 & 0.28\end{array}$

AR (January)

$-0.05-1.4$

$0.04-0.06-2.1$

$\begin{array}{llll}0.15 & -0.05 & -1.9\end{array}$

0.11

Two-Year Forecasts

CAR (rank period)

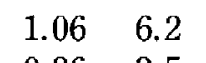

$\begin{array}{lll}0.66 & 0.92 & 6.0\end{array}$

0.65

1.02

$\begin{array}{ll}7.1 & 0.72\end{array}$

CAR (test period)

$-0.36-3.5$

$0.37-0.30-2.6$

$0.23-0.34-3.5$

0.37

AR (January)

$-0.12-5.7$

$0.62-0.11-5.0$

$0.55-0.12-6.2$

0.66

Five-Year Forecasts

CAR (rank period)

$\begin{array}{rrrrr}2.01 & 7.8 & 0.76 & 1.41 & 4.7\end{array}$

$\begin{array}{llll}0.53 & 1.98 & 7.5 & 0.74\end{array}$

CAR (test period)

$\begin{array}{lllll}-0.68 & -4.0 & 0.44 & -0.46 & -2.8\end{array}$

$\begin{array}{llll}0.26 & -0.67 & -3.9 & 0.43\end{array}$

AR (January)

0.03

$\begin{array}{lllll}0.4 & -0.04 & -0.04 & -.7\end{array}$

$\begin{array}{llll}-0.02 & 0.01 & 0.2 & -0.04\end{array}$

Note: The regressor is the rank of the earnings-growth vitile portfolio, i.e. 1 for the lowest earnings-growth portfolio and 20 for the highest. All regressions are ordinary least squares with 20 observations. To save space, intercepts are not reported.

to address this issue is to investigate the stock market performance of the earnings-growth portfolios prior to the forecast month. Table 11 shows the results for the arbitrage portfolio (this time with the sign reversed). Also shown are the Spearman rank correlations between the earnings-growth rank of each portfolio and the CAR for months 1 and $m$ of the rank period $(m=1, \ldots, 36)$. These correlations inform us how soon the stock market starts to reflect the news about future earnings that leads analysts to be optimistic or pessimistic.

Clearly, the portfolios based on one-year EPS forecasts do not behave at all like the big winners and losers in the stock market, although the portfolios based on five-year forecasts do. Based on the regressions in Table 10 (with vitile portfolios), Portfolio 20 outperforms Portfolio 1 by about 38 percent over the three-year rank period. The abnormal portfolio returns are almost perfectly positively correlated with five-year analyst earnings forecasts. These results clearly suggest that unrealistic long-term earnings forecasts may be responsible 


\section{TABLE 11. Cumulative Excess Returns for Arbitrage Portfolios, Rank Period}

\begin{tabular}{|c|c|c|c|c|c|c|}
\hline \multirow[b]{2}{*}{ Month } & \multicolumn{2}{|c|}{ One-Year Forecasts } & \multicolumn{2}{|c|}{ Two-Year Forecasts } & \multicolumn{2}{|c|}{ Three-Year Forecasts } \\
\hline & $C X_{o}-C X_{p}$ & $\rho$ & $C X_{o}-C X_{p}$ & $\rho$ & $C X_{o}-C X_{p}$ & $\rho$ \\
\hline 1 & -0.28 & -0.22 & -0.27 & -0.23 & 0.80 & 0.36 \\
\hline 3 & 0.50 & 0.17 & 0.72 & 0.19 & -0.18 & -0.05 \\
\hline 6 & -1.89 & $-0.47^{* *}$ & 0.96 & 0.15 & 4.86 & $0.74^{* * *}$ \\
\hline 9 & -3.38 & $-0.51 * *$ & 1.29 & 0.04 & 13.47 & $0.92^{* * *}$ \\
\hline 12 & -3.78 & $-0.55^{* *}$ & 0.94 & -0.02 & 13.25 & $0.78^{* * *}$ \\
\hline 15 & -3.41 & -0.36 & 4.08 & 0.38 & 12.10 & $0.69^{* * * *}$ \\
\hline 18 & -4.93 & $-0.47^{* * *}$ & 4.73 & 0.33 & 18.21 & $0.79 * * *$ \\
\hline 21 & -3.81 & -0.31 & 7.37 & $0.59 * * *$ & 29.88 & $0.92^{* * *}$ \\
\hline 24 & -4.73 & -0.41 & 7.14 & $0.59 * * *$ & 32.29 & $0.92 * * *$ \\
\hline 27 & -4.00 & -0.32 & 9.99 & $0.62^{* * *}$ & 35.50 & $0.93^{* * *}$ \\
\hline 30 & -2.79 & -0.17 & 12.49 & $0.73^{* * *}$ & 30.91 & $0.86^{* * *}$ \\
\hline 33 & 1.52 & 0.27 & 17.82 & $0.86^{* * *}$ & 37.95 & $0.92^{* * *}$ \\
\hline 36 & 2.58 & 0.32 & 18.77 & $0.83^{* * *}$ & 31.08 & $0.86^{* * * *}$ \\
\hline
\end{tabular}

Note: Spearman rank correlations ( $p$ ) are computed for vitile portfolios. The correlations marked ** are significant at the 5 percent level, and those marked ${ }^{* * *}$ are significant at the 1 percent level. $\mathrm{CX}_{\mathrm{o}}$ and $\mathrm{CX}_{\mathrm{p}}$ are as defined in Table 7 .

for the initial run-up in stock prices and also for the later substandard performance. ${ }^{14}$

\footnotetext{
${ }^{14}$ In this sample, however, there is no significant winner-loser effect. As with the size effect
} (see footnote 10), this conclusion is based on methods used by Ball and Kothari (1989). Nevertheless, the excess return data for the two-year forecasts show unusually large jumps in the first January of the test period. See Table 10. 


\section{Risk and Return}

The evidence in Chapter 3 demonstrates an inverse relationship between expected earnings growth and later abnormal returns. The issue of possible risk changes has not been fully addressed, however. Ball and Kothari (1989), as well as other authors, have criticized the early overreaction studies on this basis. They have developed innovative approaches to correct for CAPM beta risk. If the pattern in returns results from mispricing, then even returns properly adjusted for risk will exhibit it. If it results from risk shifts, however, then test period returns correctly adjusted for risk will not show a relationship with analyst-expected growth.

\section{Estimating Betas}

The purpose of estimating Ball-Kothari and other betas is to do the "proper" correction for CAPM risk changes. ${ }^{15}$ Ball and Kothari used techniques first developed by Ibbotson (1975). In this study, the data are returns on 20 earnings-growth portfolios for partly overlapping periods of 58 months, 36 months prior to each April between 1976 and 1984 (the rank period), and 21 months after each April (the test period). Because the total time period is relatively short, monthly returns were used. ${ }^{16}$ The procedure starts with portfolio returns that are equally weighted averages of returns on individual securities.

For each vitile portfolio and each April, the 58 months are broken down into

\footnotetext{
${ }^{15}$ In this context, "proper" is a relative term. Stroyny and De Bondt (1992) show that, due to heteroskedasticity, Ball-Kothari betas are systematically biased upwards for past winner stocks and biased downward for past losers. Therefore, the risk shifts between the rank and test periods are probably overestimated.

${ }^{16} \mathrm{Ball}$ and Kothari used annual returns. Even with monthly returns, there are insufficient data points to study beta-risk changes for five-year forecasts of earnings growth. As a result, I only investigate possible risk shifts around one- and two-year forecasts.
} 
five subperiods: four 12-month periods ( $\mathrm{p} 1$ through $\mathrm{p} 4$ ), and a final subperiod (p5), which contains only 10 months. To find out how the risk of the portfolios changes through event time, five time series of returns were constructed for each vitile portfolio - the first series with $\mathrm{p} 1$ returns only, the second series with $\mathrm{p} 2$ returns only, and so on. Because the portfolios are rebalanced nine times (once every April), each has four series with 108 monthly returns and one with 90 returns.

Risk and abnormal return for each event-time period $p$ and each portfolio $j$ is estimated by

$$
R_{j t}(p)-R_{f t}=\alpha_{j}(p)+\beta_{j}(p)\left(R_{m t}-R_{f t}\right)+\varepsilon_{j t}(p),
$$

where $t$ represents calendar time (in months), $R_{j t}$ is the return on portfolio $j$ for month $t, R_{f t}$ is the yield on a one-month Treasury bill (as reported by Ibbotson Associates), and $R_{m t}$ is the monthly return on the market portfolio, defined as the equally weighted portfolio of all the stocks included in the 20 portfolios. The estimated parameters $\alpha_{j}(p)$ and $\beta_{j}(p)$ are constants representing Jensen's (1968) alpha and beta-risk for portfolio $j$ in event time period $p$. With vitile portfolios, in total $100 \alpha$ 's and $100 \beta$ 's are estimated.

A somewhat different way to estimate CAPM betas is to keep the data lined up as described above but to run the market model. Here $R_{j t}(p)=\alpha_{j}(p)+$ $\beta_{j}(p) R_{m t}+u_{j t}(\phi)$ is estimated. An equally weighted portfolio of all firms listed on the NYSE serves as the market index. Again, different beta estimates were obtained for each subperiod and for each earnings-growth portfolio.

A common method of estimating betas is to run the market model for individual companies using daily returns for the rank period (between April of year $t-3$ and the end of March of year $t$ ). An equally weighted portfolio of all firms listed on the New York and American stock exchanges serves as the market index. Because there are nine forecast months (each April between 1976 and 1984), each company has up to nine betas. The betas are averaged across portfolios and across years.

\section{Results}

Table 12 shows CAPM betas for decile portfolios (D1, . . , D10). For the first two years of the rank period (subperiods $\mathrm{p} 1$ and $\mathrm{p} 2$ ) and for the test period ( $\mathrm{p} 4$ and $\mathrm{p} 5$ ), the betas are averaged. No dramatic and sudden risk shifts are apparent. Companies for which analysts are pessimistic become somewhat more risky investments during the test period; companies for which analysts are optimistic become less so. The most important result in Table 12, however, is that the betas tend to be larger for companies with high projected earnings growth, the very same firms that underperform the averages in the stock 
TABLE 12. Market-Model and Ball-Kothari Betas for Decile Portfolios Based on Projected Earnings Growth

\begin{tabular}{|c|c|c|c|c|c|c|c|}
\hline \multirow[b]{2}{*}{ Portfolio } & \multirow{2}{*}{$\frac{\text { CAPM Beta }^{a}}{\text { Subperiod }(t-3, t)}$} & \multicolumn{3}{|c|}{ Market-Model Beta ${ }^{b}$} & \multicolumn{3}{|c|}{ Ball-Kothari Beta ${ }^{b}$} \\
\hline & & Before ${ }^{c}$ & (p3) & After $^{\mathrm{d}}$ & Before $^{c}$ & (p3) & After ${ }^{d}$ \\
\hline \multicolumn{8}{|c|}{ One-Year Forecasts } \\
\hline D1 & 0.970 & 0.871 & 0.889 & 0.934 & 0.979 & 0.961 & 1.007 \\
\hline D2 & 0.969 & 0.922 & 0.939 & 0.957 & 1.022 & 1.000 & 1.031 \\
\hline D3 & 0.977 & 0.872 & 0.908 & 0.893 & 0.984 & 0.976 & 0.968 \\
\hline D4 & 0.953 & 0.847 & 0.912 & 0.885 & 0.969 & 0.987 & 0.956 \\
\hline D5 & 0.946 & 0.838 & 0.895 & 0.871 & 0.961 & 0.969 & 0.942 \\
\hline D6 & 0.965 & 0.869 & 0.895 & 0.875 & 0.990 & 0.962 & 0.945 \\
\hline D7 & 0.982 & 0.896 & 0.936 & 0.934 & 1.015 & 0.997 & 1.008 \\
\hline D8 & 0.993 & 0.899 & 0.931 & 0.945 & 1.013 & 1.000 & 1.014 \\
\hline D9 & 1.025 & 0.912 & 0.963 & 0.979 & 1.038 & 1.031 & 1.054 \\
\hline D10 & 1.047 & 0.930 & 1.052 & 1.007 & 1.031 & 1.117 & 1.074 \\
\hline
\end{tabular}

Two-Year Forecasts

$\begin{array}{rlllllll}\text { D1 } & 0.979 & 0.822 & 0.853 & 0.897 & 0.966 & 0.948 & 0.979 \\ \text { D2 } & 0.915 & 0.758 & 0.845 & 0.854 & 0.906 & 0.932 & 0.946 \\ \text { D3 } & 0.902 & 0.757 & 0.834 & 0.833 & 0.950 & 0.936 & 0.938 \\ \text { D4 } & 0.925 & 0.817 & 0.844 & 0.854 & 1.031 & 0.959 & 0.949 \\ \text { D5 } & 0.960 & 0.832 & 0.899 & 0.868 & 1.015 & 1.009 & 0.970 \\ \text { D6 } & 0.921 & 0.776 & 0.842 & 0.840 & 0.960 & 0.933 & 0.934 \\ \text { D7 } & 0.985 & 0.796 & 0.853 & 0.864 & 1.013 & 0.991 & 0.973 \\ \text { D8 } & 1.047 & 0.860 & 0.920 & 0.975 & 1.037 & 1.022 & 1.090 \\ \text { D9 } & 1.061 & 0.853 & 1.025 & 0.984 & 1.057 & 1.125 & 1.091 \\ \text { D10 } & 1.128 & 0.872 & 1.039 & 1.032 & 1.063 & 1.146 & 1.131\end{array}$

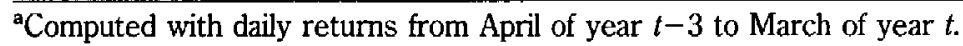

${ }^{b}$ Calculated from monthly returns.

${ }^{c}$ Average for subperiods $\mathrm{p} 1$ and $\mathrm{p} 2$.

${ }^{\mathrm{d} A v e r a g e}$ for subperiods $\mathrm{p} 4$ and $\mathrm{p} 5$.

market. The betas are larger whichever way one looks at the data. Prior to the test period, the difference in the betas of the extreme decile portfolios (D10 vs. D1) is roughly between 0.060 and 0.150 for the one-year forecasts and between 0.050 and 0.200 for the two-year forecasts. During the test period, the difference narrows, but D10 remains more risky than either D1 or the portfolios in the middle. These findings seem to eliminate CAPM beta risk as an explanation of the excess returns discussed in Chapter 3. If anything, the data 
TABLE 13. Market-Adjusted Excess Returns and Jensen's Alphas for Decile Portfolios Based on Projected Earnings Growth

\begin{tabular}{|c|c|c|c|c|c|c|}
\hline \multirow[b]{2}{*}{ Portfolio } & \multicolumn{3}{|c|}{ Market-Adjusted Excess Returns } & \multicolumn{3}{|c|}{ Jensen's Alphas ${ }^{\mathrm{a}}$} \\
\hline & Before $^{b}$ & (p3) & After ${ }^{\mathrm{C}}$ & Before ${ }^{b}$ & (p3) & After ${ }^{c}$ \\
\hline \multicolumn{7}{|c|}{ One-Year Forecasts } \\
\hline D1 & 1.376 & -5.145 & -1.433 & 1.356 & -5.648 & -2.464 \\
\hline $\mathrm{D} 2$ & 0.379 & -3.566 & 1.603 & 0.544 & -3.128 & 1.481 \\
\hline D3 & 1.449 & -2.937 & 1.380 & 1.244 & -2.938 & 1.080 \\
\hline D4 & -1.066 & 0.605 & 1.357 & -0.934 & 0.878 & 1.628 \\
\hline D5 & -0.268 & -0.833 & -0.476 & 0.067 & -0.683 & -0.069 \\
\hline D6 & -0.966 & 1.008 & 1.198 & -0.618 & 1.358 & 1.803 \\
\hline D7 & 1.487 & 1.807 & -0.285 & 1.586 & 2.229 & 0.269 \\
\hline D8 & 0.580 & 3.153 & 0.043 & 0.414 & 3.182 & -0.033 \\
\hline D9 & -0.884 & 3.584 & -1.557 & -0.944 & 3.579 & -1.680 \\
\hline D10 & -2.088 & 2.323 & -1.831 & -2.415 & 1.977 & -2.361 \\
\hline \multicolumn{7}{|c|}{ Two-Year Forecasts } \\
\hline D1 & 0.126 & -5.596 & -1.429 & -0.254 & -6.156 & -2.638 \\
\hline D2 & -2.894 & -4.110 & 1.930 & -2.621 & -3.607 & 2.045 \\
\hline D3 & -0.302 & -1.941 & 1.329 & 0.442 & -1.286 & 1.763 \\
\hline D4 & -0.056 & -4.421 & 0.743 & 0.383 & -3.802 & 1.200 \\
\hline D5 & -1.994 & 0.124 & 1.154 & -2.262 & 0.521 & 1.429 \\
\hline D6 & -0.840 & 0.926 & 0.449 & -1.091 & 0.842 & 0.700 \\
\hline D7 & 0.693 & -0.135 & -0.134 & 1.115 & 0.513 & 0.412 \\
\hline D8 & 0.891 & 1.597 & 0.017 & 0.728 & 1.685 & 0.307 \\
\hline D9 & 1.240 & 5.823 & -1.810 & 1.010 & 5.607 & -2.549 \\
\hline D10 & 3.136 & 7.731 & -2.249 & 2.669 & 6.528 & -2.945 \\
\hline
\end{tabular}

${ }^{a}$ Annualized; based on regressions with monthly returns.

'Average for subperiods $\mathrm{pl}$ and $\mathrm{p} 2$.

${ }^{c}$ Average for subperiods $\mathrm{p} 4$ and $\mathrm{p} 5$.

suggest that these earlier results understate the profitability of the arbitrage portfolios.

Table 13 presents annualized Jensen's alphas that correspond to the Ball-Kothari betas of Table 12. The table also lists annualized market-adjusted excess returns (the return on the market portfolio is the equally weighted average return on all firms in the sample). These excess returns assume that the risk is the same for each decile portfolio. Ignoring portfolio D1, the test period alphas for the two-year forecasts clearly decline as hopes for future 
FIGURE 6. Excess Returns and Jensen's Alphas for 20 Portfolios

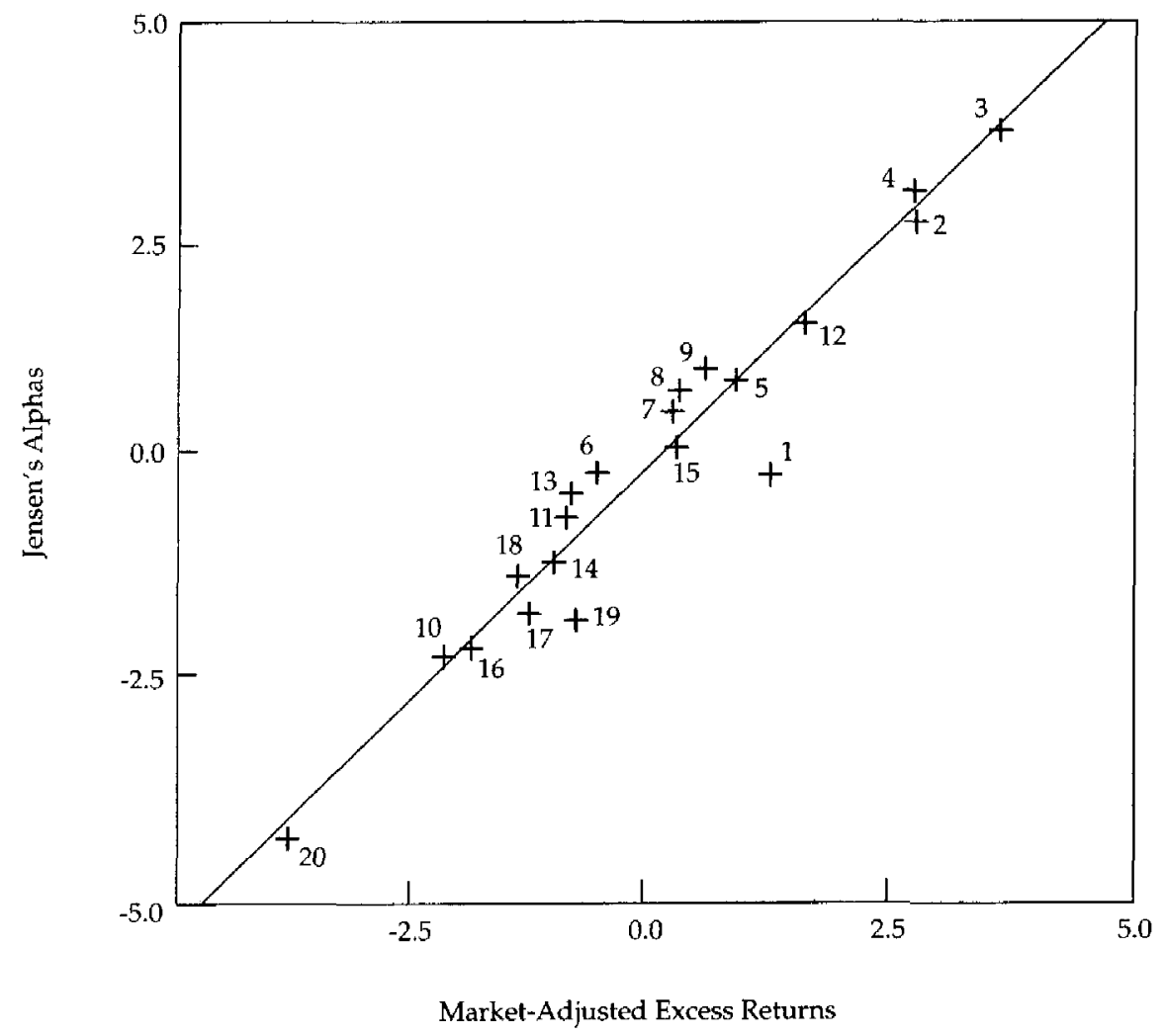

earnings growth increase. This pattern is the exact reverse of what happens during year $t-1$. Because the beta differences between the portfolios are so small, the market-adjusted excess returns look quite similar to the alphas. Figure 6 shows a scatter diagram (with a fitted regression line) for vitile portfolios. Each number in the figure refers to one of the portfolios.

Does an arbitrage portfolio that exploits unrealistic forecasts of earnings growth still earn significant excess returns after controlling for risk with Ball-Kothari betas? To answer this question, the performance of the extreme quintile portfolios was compared for the months in subperiod $\mathrm{p} 4$ (the first 12 months after the April forecast). The return differential was regressed on the market risk premium. Two more regressions have only the returns on Q1 or Q5 as dependent variables. For the one-year forecasts, the alpha of the arbitrage portfolio is 0.253 percent a month $(t=1.45)$ and the beta is $-0.070(t=$ 
$-1.89)$. For the two-year forecasts, the alpha is 0.443 a month $(t=1.94)$ and the beta is $-0.171(t=-3.46)$. As in Chapter 3 , the results are stronger for the two-year forecasts, and they appear to be statistically significant. On an annual basis, the excess returns amount to about 5 percent. Roughly half of the excess returns derive from each quintile. The monthly alpha is 0.237 percent $(t$ $=1.78)$ for $\mathrm{Q} 1$, and it is -0.206 for $\mathrm{Q} 5(t=-1.59)$. 


\section{Conclusion}

Previous research finds mean reversion in stock prices, both cross-sectionally (De Bondt and Thaler 1985, Ball and Kothari 1989, and Chopra et al. 1991) and at the aggregate level (Fama and French 1988, Poterba and Summers 1988). Broadly speaking, this phenomenon could have three sets of (not mutually exclusive) explanations. One view is that mean reversion does not really exist but amounts to a statistical artifact. A second view is that mean reversion is to be expected if either the objective riskiness of a stock or the rationally required compensation for risk systematically changes through time, perhaps with the business cycle. A third view is that mean reversion occurs because markets are inefficient; that is, price frequently deviates from intrinsic value.

This study in behavioral finance examined the possibility that the market overreacts to news about future earnings. ${ }^{17}$ The data broadly support the hypothesis. For the 1976-86 period, an inverse relationship existed between expected earnings growth and subsequent returns. Because it takes time for forecasts to be proven wrong, the statistical link strengthens as the test period lengthens. Also consistent with overreaction, share price reversals appear to be somewhat larger for five-year forecasts. In his book The Intelligent Investor, Benjamin Graham (1959, p. 133) observed that ". . . no one really knows anything about what will happen in the distant future but analysts and investors have strong views on the subject just the same." The data seem to agree with this assessment. Perhaps long-term earnings forecasts are like "castles in the air."

The investment implications of this study are promising but still somewhat

\footnotetext{
${ }^{17}$ There are at least two more overreaction theories. One is that risk perceptions move too much and that they are a function of prior stock returns (De Bondt 1992). The second hypothesis is that the market has a life of its own and that trading is to some extent self-generating-that is, the market is driven by news about its own behavior. See French and Roll (1986) and the survey evidence relating to the 1987 stock market crash summarized in Shiller (1990).
} 
tentative. More data and further tests are necessary to determine whether the supposed excess returns for the extreme portfolios are economically significant; for example, transaction costs should be considered. Probably the most important extension is in the area of five-year earnings forecasts. At the present time, the time series of these forecasts may be too short to allow truly reliable inferences, and the forecasts are concentrated in too few industries. Nevertheless, these forecasts clearly seem to offer attractive investment opportunities. The study should also be extended to include small publicly listed firms. Chances are that investor overreaction wreaks the most havoc with respect to the pricing of small firms (see Chopra et al. 1991). 


\section{References}

Ball, Ray, and S.P. Kothari. 1989. "Nonstationary Expected Returns: Implications for Tests of Market Efficiency and Serial Correlation in Returns." Joumal of Financial Economics (November):51-74.

Bernard, Victor L. 1991. "Stock Price Reactions to Earnings Announcements: A Summary of Recent Anomalous Evidence and Possible Explanations." Working Paper, Harvard Business School (March).

Brooks, L.D., and D.E. Buckmaster. 1976. "Further Evidence on the Time-Series Properties of Accounting Income." Journal of Finance (December):1359-73.

Chopra, Navin; Josef Lakonishok; and Jay R. Ritter. 1992. "Performance Measurement Methodology and the Question of Whether Stocks Overreact." Forthcoming in Journal of Financial Economics.

De Bondt, Werner F.M. 1992. "Betting on Trends: Intuitive Forecasts of Financial Risk and Return." Working paper, School of Business, University of Wisconsin-Madison (January).

De Bondt, Werner F.M., and Richard H. Thaler. 1985. "Does the Stock Market Overreact?" Joumal of Finance (July): 793-805.

. 1987. "Further Evidence on Investor Overreaction and Stock Market Seasonality." Journal of Finance (July):557-81.

57. . 1990. “Do Security Analysts Overreact?" American Economic Review (May):52-

De Long, J. Bradford; Andrei Shleifer; Lawrence H: Summers; and Robert J. Waldman. 1990. "Noise Trader Risk in Financial Markets." Journal of Political Economy (98):703-38.

Elton, Edwin J.; Martin J. Gruber; and Mustafa N. Gultekin. 1984. "Professional Expectations: Accuracy and Diagnosis of Errors." Joumal of Financial and Quantitative Analysis (December): 351-65.

Fama, Eugene F., and Kenneth R. French. 1988. "Permanent and Temporary Components of Stock Prices." Joumal of Political Economy (April):246-73.

French, Kenneth R., and Richard Roll. 1986. "Stock Return Variances: The Arrival of Information and the Reaction of Traders." Journal of Financial Economics (September):5-26.

Ibbotson, Roger G. 1975. "Price Performance of Common Stock New Issues." Joumal of Financial Economics (September):235-72.

Jensen, Michael C. 1968. "The Performance of Mutual Funds in the Period 1945-1964." Journal of Finance (23):389-415. 
Kahneman, Daniel, and Amos Tversky. 1972. "Subjective Probability: A Judgment of Representativeness." Cognitive Psychology (3):430-54.

1973. "On the Psychology of Prediction." Psychological Review (80):237-51.

Klein, April. 1990. "A Direct Test of the Cognitive Bias Theory of Share Price Reversals." Journal of Accounting and Economics (July): 155-66.

Malkiel, Burton G. 1963. "Equity Yields, Growth, and the Structure of Share Prices." American Economic Review (December):1004-31.

Merton, Robert C. 1987. "A Simple Model of Capital Market Equilibrium with Incomplete Information." Journal of Finance (July):483-510.

O'Brien, Patricia. 1988. "Analysts' Forecasts as Earnings Expectations." Journal of Accounting and Economics (January):53-83.

. 1991. "Are Analyst Overestimates Due to Macroeconomic Shocks or Bias?" Working Paper, School of Business Administration, University of Michigan (April).

Poterba, James M., and Lawrence H. Summers. 1988. "Mean Reversion in Stock Prices: Evidence and Implications." Joumal of Financial Economics (October):27-59.

Rendleman, Richard J., Jr.; Charles P. Jones; and Henry A. Latane. 1982. "Empirical Anomalies Based on Unexpected Earnings and the Importance of Risk Adjustments." Journal of Financial Economics (November):269-87.

Shiller, Robert J. 1990. Market Volatility. Cambridge, Massachusetts: MI'T Press.

Shleifer, Andrei, and Lawrence H. Summers. 1990. "The Noise Trader Approach to Finance." Journal of Economic Perspectives (Spring):19-33.

Stroyny, Alvin S., and Werner F.M. De Bondt. 1992. "Heteroskedasticity and the Estimated Risk of Winners and Losers." Working Paper, School of Business, University of Wisconsin (January).

Zarowin, Paul. 1989. "Does the Stock Market Overreact to Corporate Earnings Information?" Journal of Finance (December): 1385-1400. 